Original Research Paper

\title{
Augmented Reality Application for Teaching Basic Operations with Fractions of the Same Denominator
}

\author{
Hernández Pérez Andrea Ivonne, Mendoza Pérez Marco Alberto and Cruz Flores René Guadalupe \\ Department of Computer Engineering, Centro Universitario UAEM Valle de Chalco, Estado de México, México
}

\author{
Article history \\ Received: 01-04-2020 \\ Revised: 05-05-2020 \\ Accepted: 25-07-2020 \\ Corresponding Author: \\ Hernández Pérez Andrea \\ Ivonne \\ Department of Computer \\ Engineering, Centro \\ Universitario UAEM Valle de \\ Chalco, Estado de México, \\ México \\ Email: hivonnedz@gmail.com
}

\begin{abstract}
In this study, an Augmented Reality (AR) application for the teaching of basic operations with fractions of the same denominator was made. Prototype Methodology was used for its develop. In the application striking figures designs are visualized in three-Dimensional (3D), to the students' perspective, those help to represent the explanation in the best way with the process of the basic operations with fractions: Addition, subtraction, multiplication, division and an exercises section. All this is to the students comprehend the fractions topic totally, using computational technology as a support in the teaching-learning process in a dynamic, friendly, creative and innovate way, also easy to manipulate by the users, catching students attention to learn this kind of topics or even another in a significate way. The application was focused to fourth grade elementary students, it is important to say that nowadays an application like that do not exist. Once the application develop finished a demonstration of the application was done in a group of fourth grade students and a questionnaire was applied them, obtaining satisfactory results in their learning.
\end{abstract}

Keywords: Application, Augmented Reality, Fractions, Prototype Methodology, Teaching

\section{Introduction}

Since ancient time, fractions were known for Babylonians, Egyptians and Greeks; they used them to solve everyday issues, as for example, bread distribution, pyramid construction and to know the measures to study the farmland (Sanguino, 2019).

Fractions are equal parts of a whole number. Mathematically they are representing by two numbers which are separate between them by a horizontal line called fractional line. The number over the line is called numerator and the number under the line is called denominator. The numerator is the number of parts that wants to take from the fractional part and the denominator is the number of parts in which the number has been divided (Educativo, 2011).

Nowadays, Augmented Reality applications for teaching fractions with the same denominator do not exist, that topic is hard to understand for the students, they do not comprehend it totally, this is something worried because since fourth grade at elementary school students use operations with fractions and if they do not comprehend that topic at that grade, they will have issues in another education levels. Based on this, an Augmented Reality application for training fourth grade elementary students in the arithmetic operations of fractions with same denominator (addition, subtraction, multiplication and division) was designed, developed and implemented.

Azuma (1997) defines that Augmented Reality have the following three characteristics:

1. Combines real and virtual elements

2. Interactive in real time

3. Registered in 3D

"Augmented Reality, from now AR, is a technology which overlaps to a real image obtained through a screen, images, 3D models or another kind of information generated by a computer" (Prendes, 2015). After that definition, a user can be in a physical and real environment and can have a free interaction with those $3 \mathrm{D}$ objects, images or another kind of information generated on a computer, this is the big difference between Augmented Reality and Virtual Reality. According to (BBC, 2016), application company AR Soft mentions that Virtual Reality focuses more on introducing the user in a different world, while Augmented Reality allows the user to view the information generated by a computer in a real world. Virtual Reality, as its name says, is a virtual world completely designed in 3D, like a fantasy world and 
Augmented Reality adds virtual elements to a reality that already exist. Figure 1 is an example of how Augmented Reality is used.

To explain in an easier way Augmented Reality concept (Telefónica, 2011) invites to do a reference to the senses that humans possess with which the world is perceived. The physical reality is understood through the sight, hearing, smell, taste and touch, so Augmented Reality comes to enhance those five senses with a new lens which complement the information of the real world with the information of the digital world. Augmented Reality is a technology which allows the overlap of images or virtual information above images from the real world and in real time. The environment that is created is one in where the information and virtual objects are fused with the real objects. Figure 2 shows Augmented Reality working, this technology is a lens which the physical world is viewed and at that time overlaps digital information above the physical environment, the digital information is in the network.
In the review to the book Realidad Aumentada. Tecnología para todos. It is mentioned that the authors synthesize to Augmented Reality as a combination of digital information and physical information in real time, through different technological devices, adding a virtual synthetic part to the real and making better the comprehension of the information which was added to the reality (Pérez, 2016).

According to (Heras and Villarreal, 2007) if the real environment is dominant and virtual objects are added on it, it is called Augmented Reality.

Augmented Reality allows new ways of interaction in the environment, for that, it applies in different scopes as in the medicine, industry, advertising, entertainment and education (Reinoso, 2012). Sectors as the military, manufacture and automobile maintenance and aeronautical and in the training of skills and abilities have been using more the technology of Augmented Reality (Telefónica, 2011).

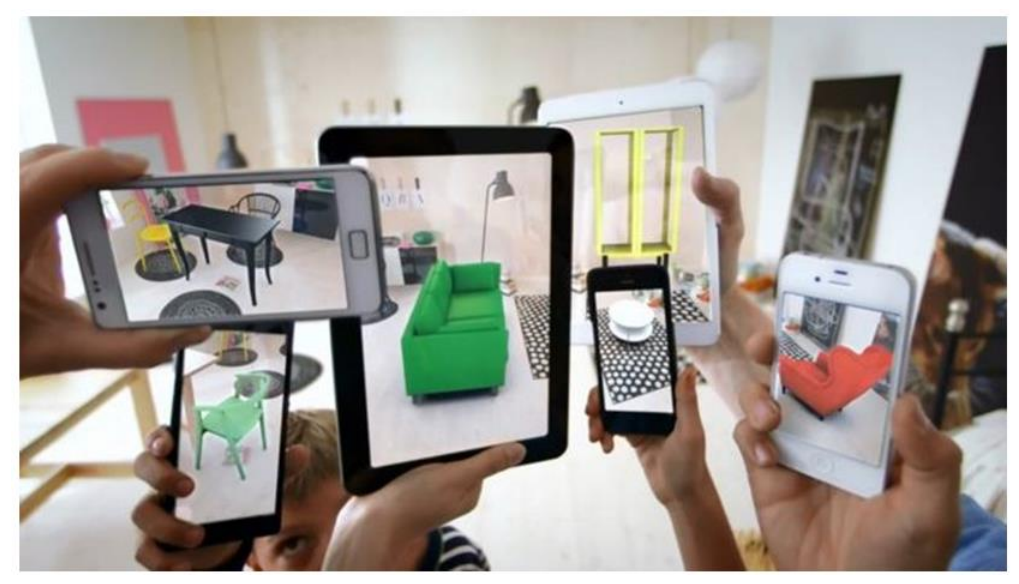

Fig. 1: Example of how augmented reality is used

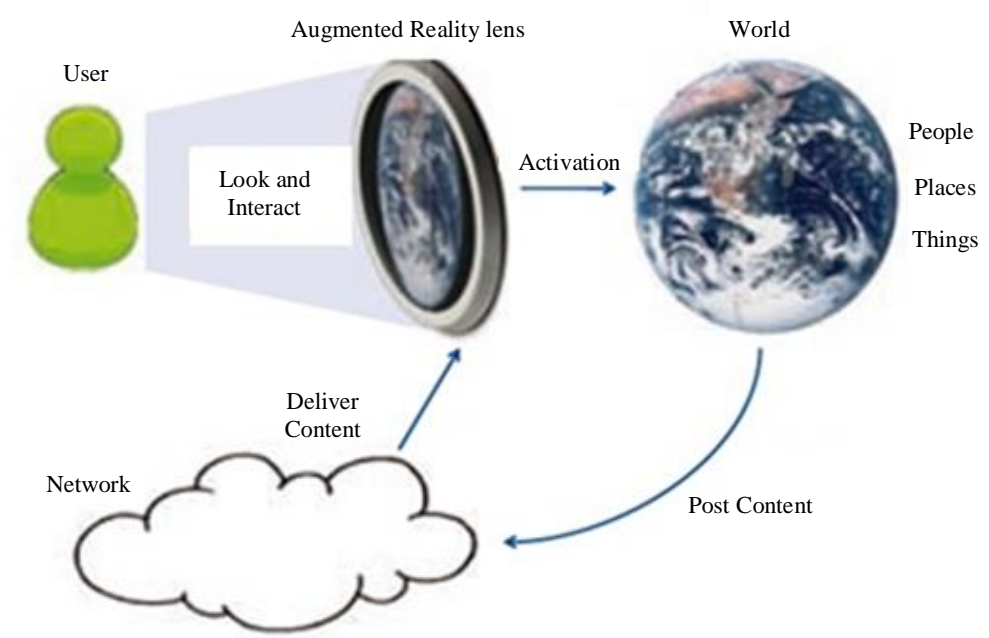

Fig. 2: Augmented reality working 
The application made in this work is applied to the education area to serve as a support in the teachinglearning process, in that area Augmented Reality has been very well accepted and there are variety of research works which demonstrate the positive impacts that exist in the education area.

In the education area (López-García and Gutiérrez-Niño, 2018) consider that Augmented Reality has a high potential of develop and provides a great value adding to the teaching-learning processes.

In the work of (Montecé-Mosquera et al., 2017) it is mentioned that Augmented Reality is gaining ground in a constant way and it do it giving to know all of its big benefits in different environments, in the educative scope, there are already sites that propose to the teacher use technological tools in the classroom. The schools' authorities are agree with the use of technologies in the classroom, they consider that any technological contribution is welcome if achieves a positive change in the educational field.

According to (Samihah et al., 2017) the implementation of Augmented Reality has been improving in the last two decades. The factors which drives the use of Augmented Reality in education are the advancement of technologies which makes possible the develop learning tools, benefits that provides to the education sector, potential for the expansion in a continuous way of the learning experience and the numerous research works in its area. Some key factors which influence in any way to the acceptance of Augmented Reality are the following (Samihah et al., 2017):

1. Curriculum. Augmented Reality experiences need to be designed identifying what subjects or concepts are best taught using this technology, considering the curriculum and pedagogy

2. Stability of the interaction. Effective and stable applications that can assure a free interaction without any problem, satisfying the user expectations

3. Self-learning capability. Self-learning is promoted because the interaction with Augmented Reality system can be done by oneself, without any help or orientation from any teacher or from the parents

4. Parent's involvement. The contribution of the parents in any point or in the way to use the technology

5. Student's background. Conditions and context of the students, for example, skills, living conditions, disabilities, etc.

6. Platform. Tools or devices that are required to implement Augmented Reality applications

As another technological tool, Augmented Reality has to be used in a correct way, looking for its inclusion in a positive way in the teaching-learning process, so its influence can be evident in the results to the obtaining of new knowledge (Cárdenas et al., 2018).
To the design of 3D models, the software used were the following.

\section{MagicaVoxel}

Is a $3 \mathrm{D}$ modeling software which based on voxels assembly, is a free lightweight 8-bit Voxel Art editor. Is available on Windows and Mac. Was developed by Ephtracy and available since 2015. Its original format is VOX only for 3D models and PNG for image exports or palette files (MVCW, 2020).

\section{Blender}

Free and open source 3D creation software, it allows modeling, animation, simulation, rendering, compositing and motion tracking and even video editing and game creation, furthermore, is cross-platform and runs on operating systems like Linux, Windows and Mac. Everyone is free to use Blender to whatever purpose; it can be commercially or for education (Blender, 2020).

Blippar was used to develop the application, so important information about that software is the following.

\section{Blippar}

Company specialized in Augmented Reality since 2011 (Blippar, 2020). Blippar has its website where projects can be created; also, it has a mobile application which helps to those projects are view in Augmented Reality.

\section{Methodology}

The methodology used in this paper was prototype, is used to the user has a preliminary view about software, it is based on test the software and see if there is a fail, if the user does not like any part of the prototype it means that the test failed, so the error have to be corrected until the user is satisfied with the software (EcuRed, 2019).

Prototype Methodology is an evolutionary process; every version which is developed is more complete for the software. The prototype works like a first system, it evolves step by step into the actual system (Pressman, 2010).

Prototype has the following phases (Pressman, 2010):

- Identify requirements. Defining all the overall objectives and identify all the software requirements

- Quick design. Starting modeling, focuses more on representing aspects of the software which will be visible to end users

- Construction prototype. Developing the software, implementing all the things that were done in the quick design, all the requirements have to do in the best way

- Deployment, delivery and feedback. The software is de deployed and evaluated by the end users, they help with the feedback to the software ca be better 
Every phase of the Prototype Methodology is detailed below based on the application which was developed in this paper.

\section{Identify Requirements}

Gathering information was done, this information was in the introduction, topics that were considered were: Fractions, Augmented Reality, Prototype Methodology and important information about the software that were used. All the gathering information were done to know and relate deeper every aspect involved in the develop of this application.

An use case diagram was done to see the interaction between the application and the user. Figure 3 shows the diagram.

\section{Quick Design}

Firstly two more diagrams were done, the first was the flowchart, it was done to see the application behavior through the processes that are done while the user interact with it, Fig. 4 shows it; the second diagram was a sequence diagram, it shows the application interaction through the time, Fig. 5 shows a part of the interaction between two interfaces.
The Voxel Art helped as an inspiration to the elaboration of the 3D models. Voxel Art is do whatever figure using voxels, a voxel is the smallest cubit unit that makes up a 3D object, is a pixel but in 3D (Perán, 2014). Voxel Art is very striking at first sight, doing the models in this way was a good idea because the application is focused to fourth grade elementary students, so the aim of made striking figures and objects to catch their attention immediately is met.

To do the models, the software used is called MagicaVoxel, it has a default color palette but also own palettes can be made, the development environment is in 3D and the scale size can be configured, it has different brushes which any figure can be created, it has a console in which the figures are manipulated by commands, also it has the rendering option to observe detail how the figures or objects created look. Figure 6 shows the development environment as soon as the software runs.

Firstly the logo and the application name was created, Fig. 7 and 8 shows them, they were done with a lot of imagination and using striking and matching colors.

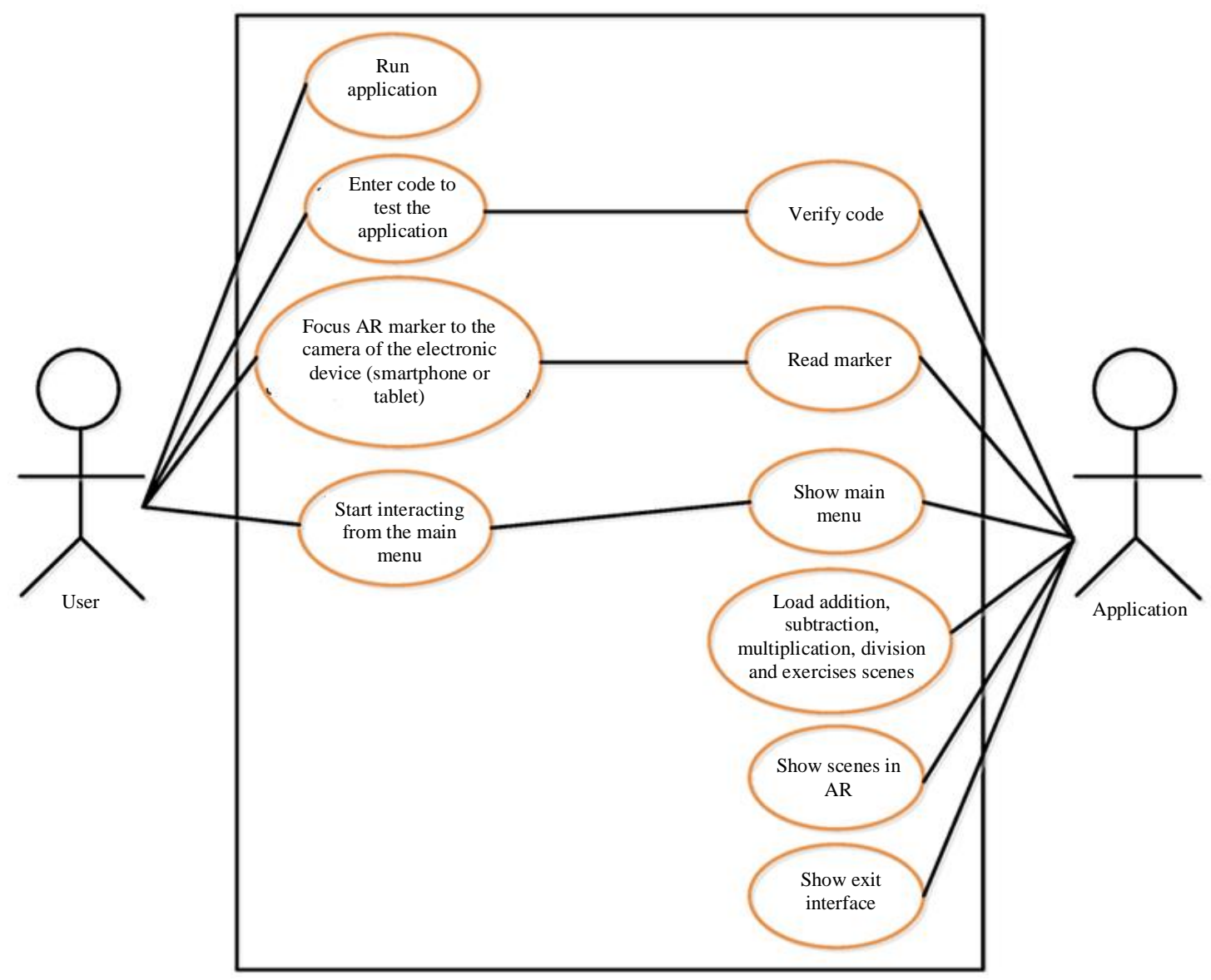

Fig. 3: Use case diagram of the application 
Hernández Pérez Andrea Ivonne et al. / Journal of Computer Science 2020, 16 (7): 1042.1062 DOI: $10.3844 /$ jessp.2020.1042.1062

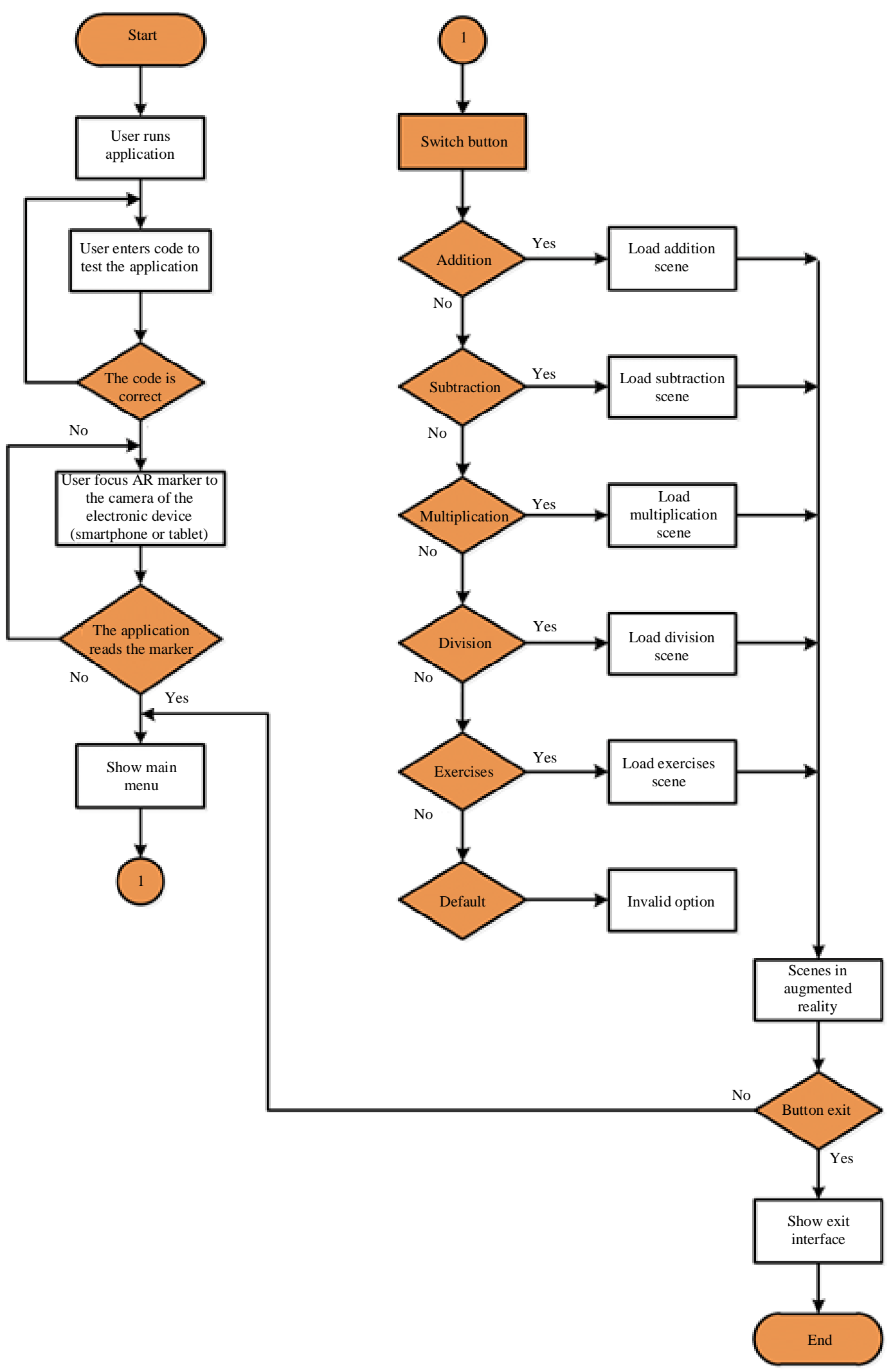

Fig. 4: Flowchar application 


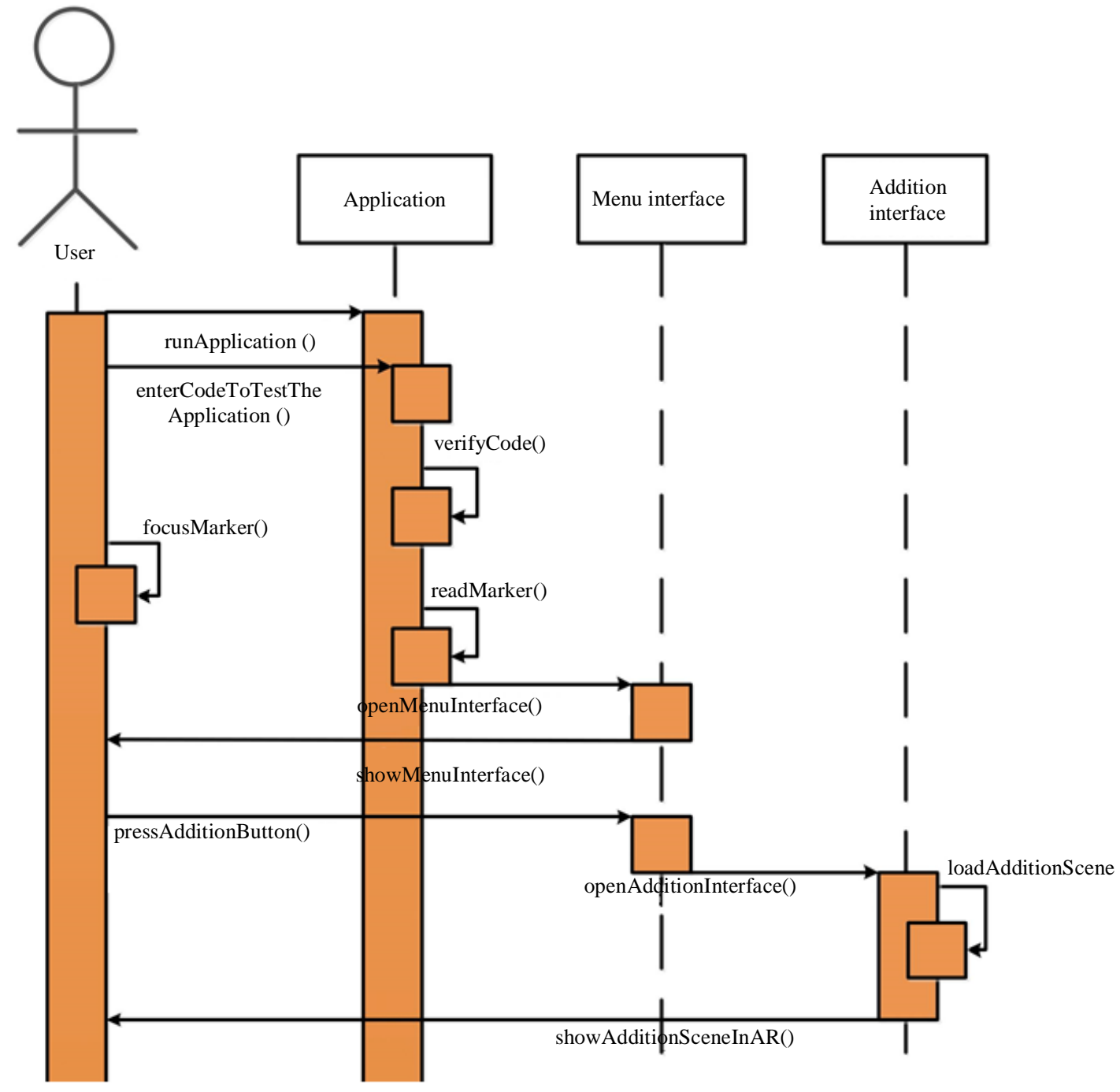

Fig. 5: Sequence diagram of the application

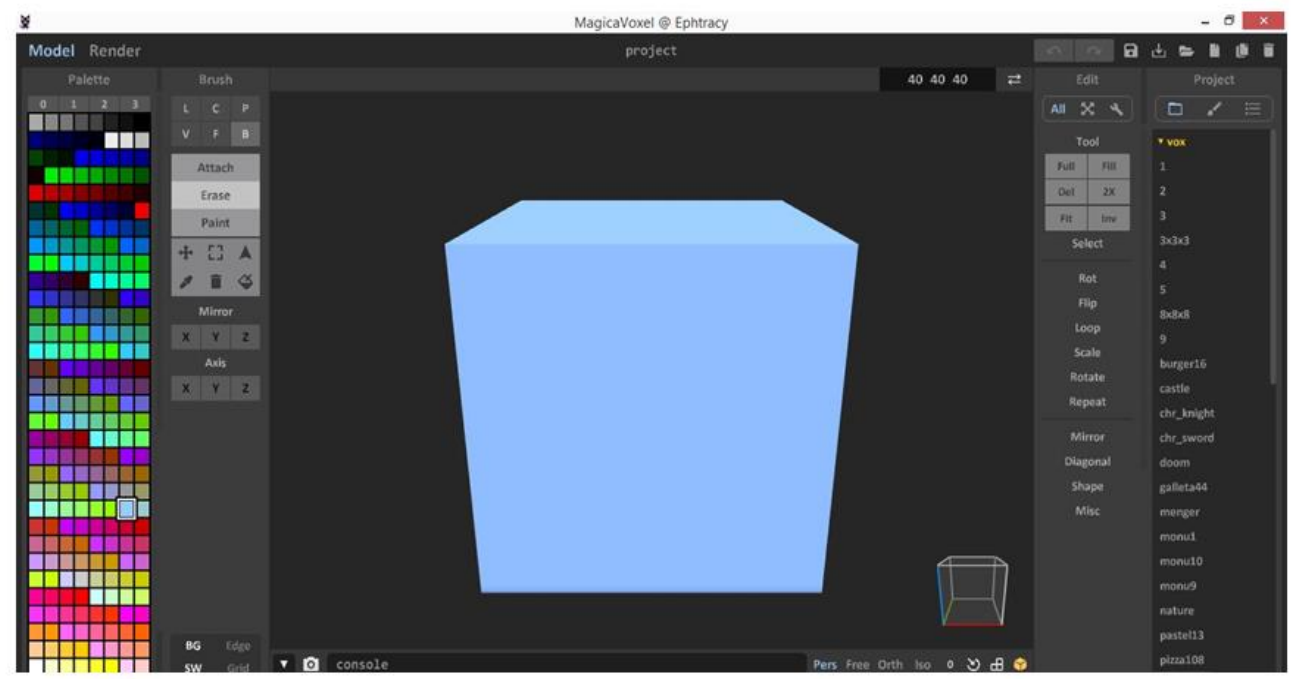

Fig. 6: MagicaVoxel development environment 
Hernández Pérez Andrea Ivonne et al. / Journal of Computer Science 2020, 16 (7): 1042.1062 DOI: $10.3844 / j \operatorname{cssp.2020.1042.1062}$

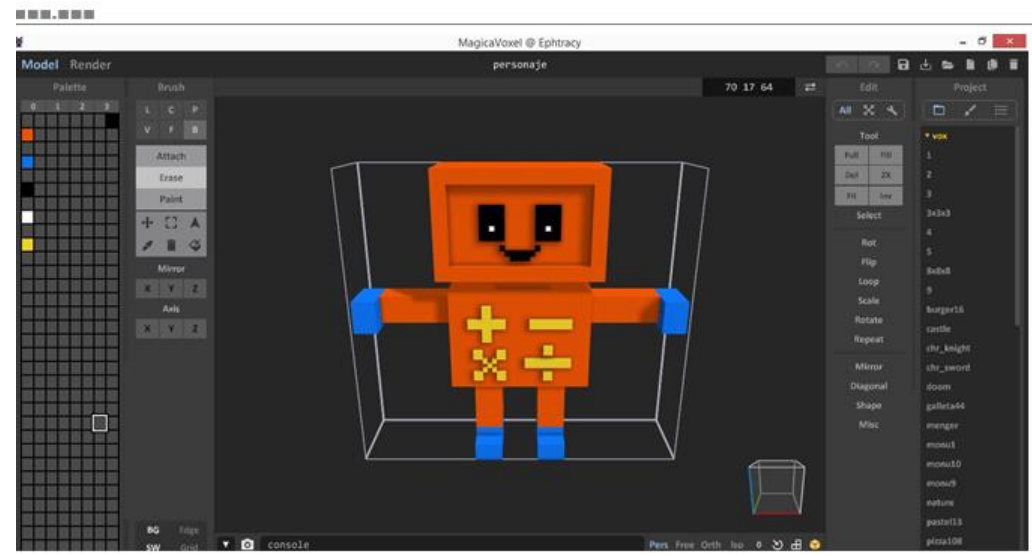

Fig. 7: Application logo

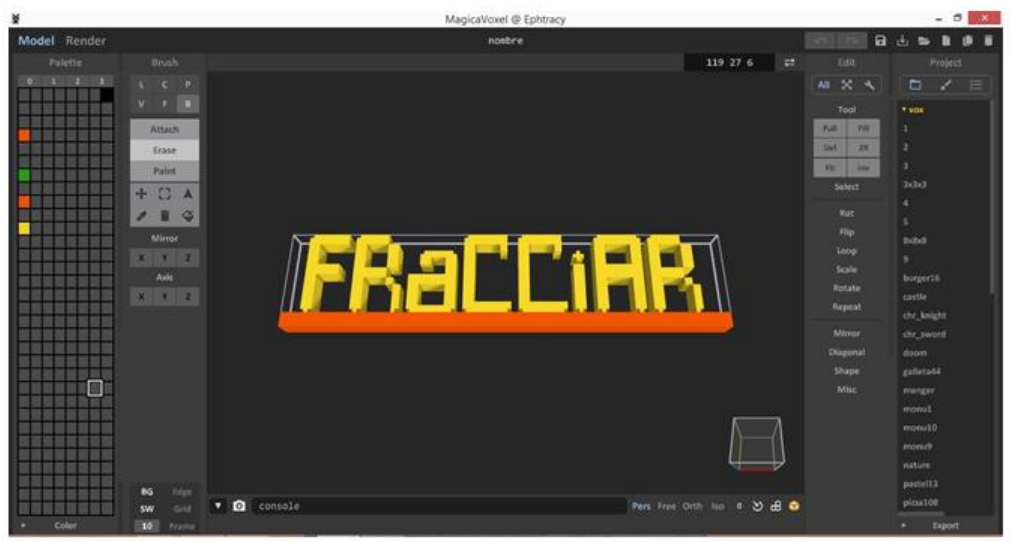

Fig. 8: Application name

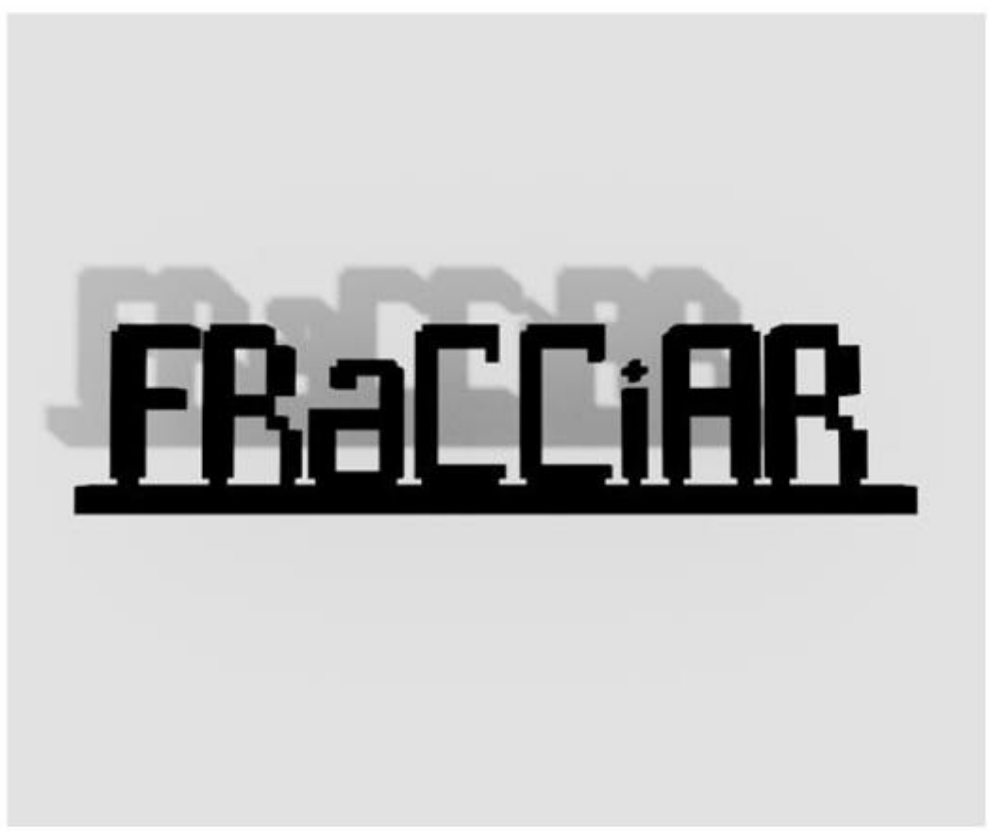

Fig. 9: Augmented reality marker 
Hernández Pérez Andrea Ivonne et al. / Journal of Computer Science 2020, 16 (7): 1042.1062 DOI: $10.3844 /$ jessp.2020.1042.1062

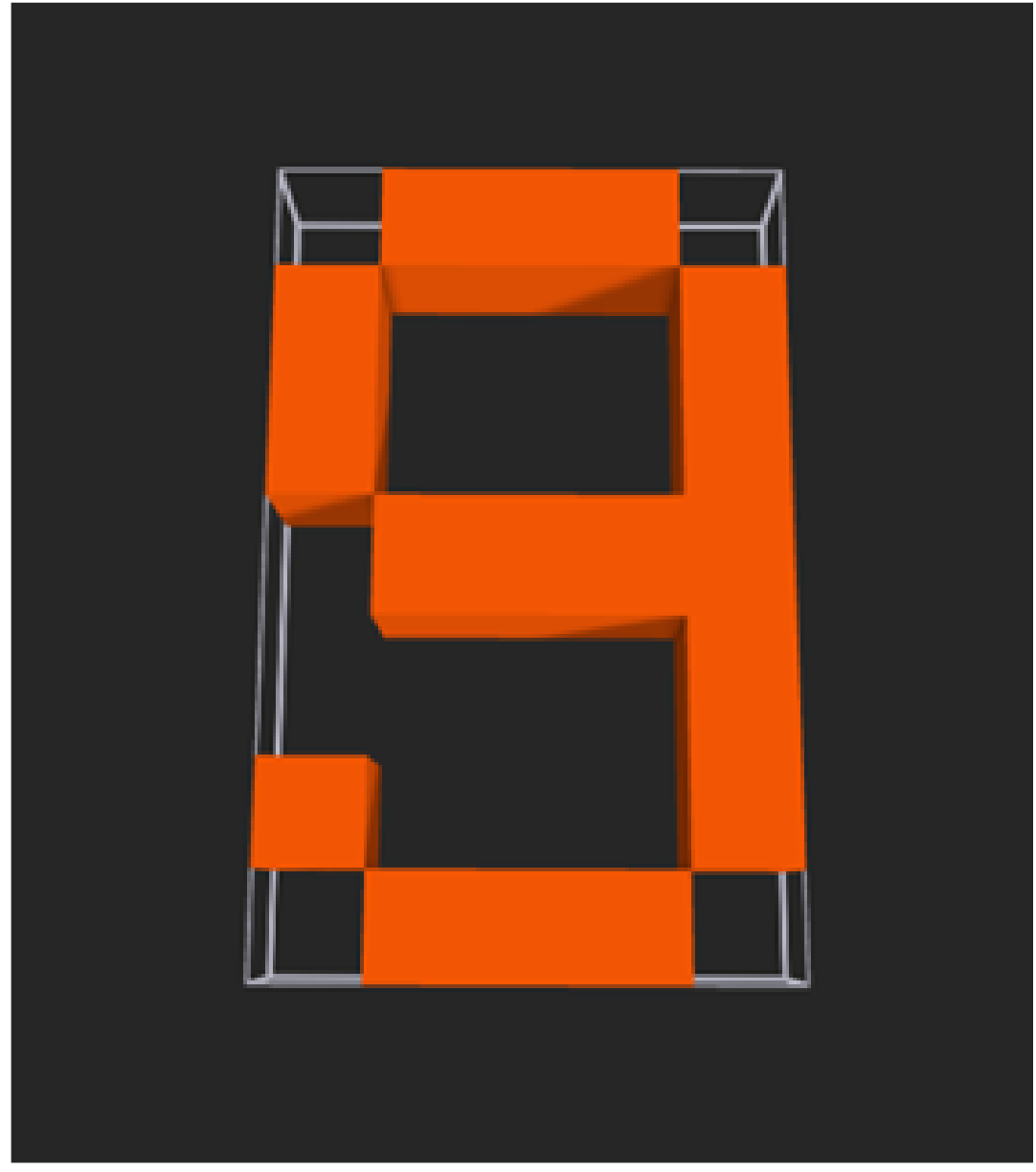

Fig. 10: Example of a created number

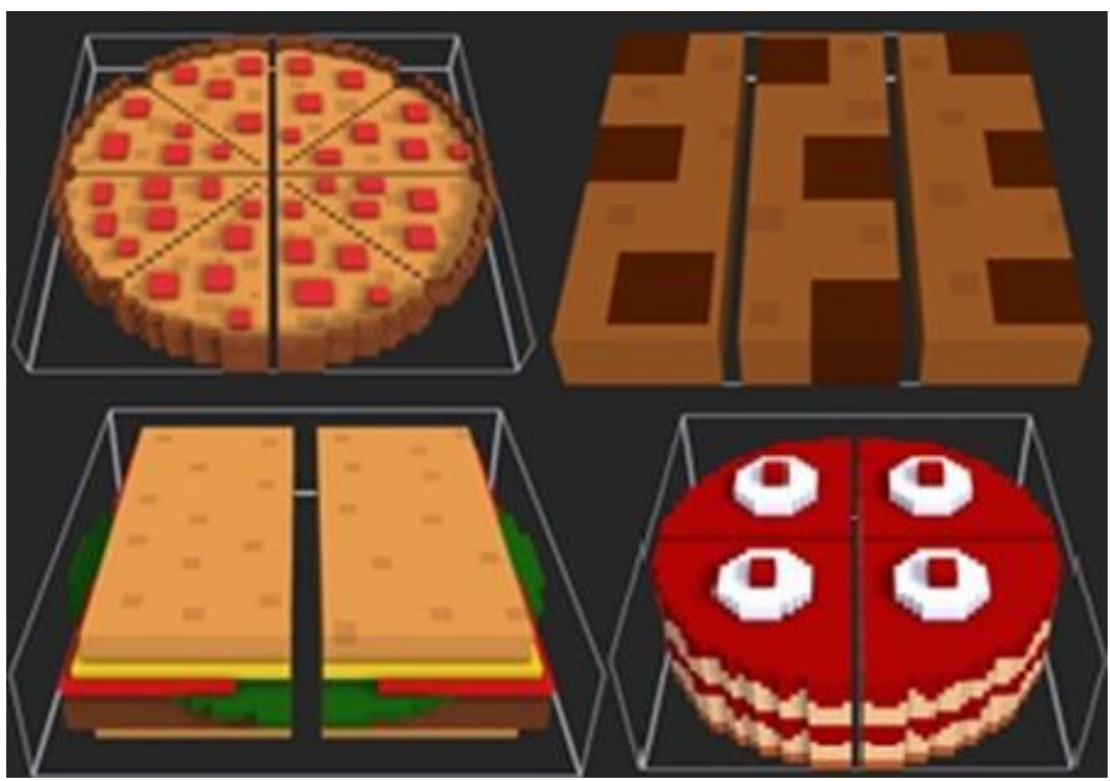

Fig. 11: Figures to represent fractions 


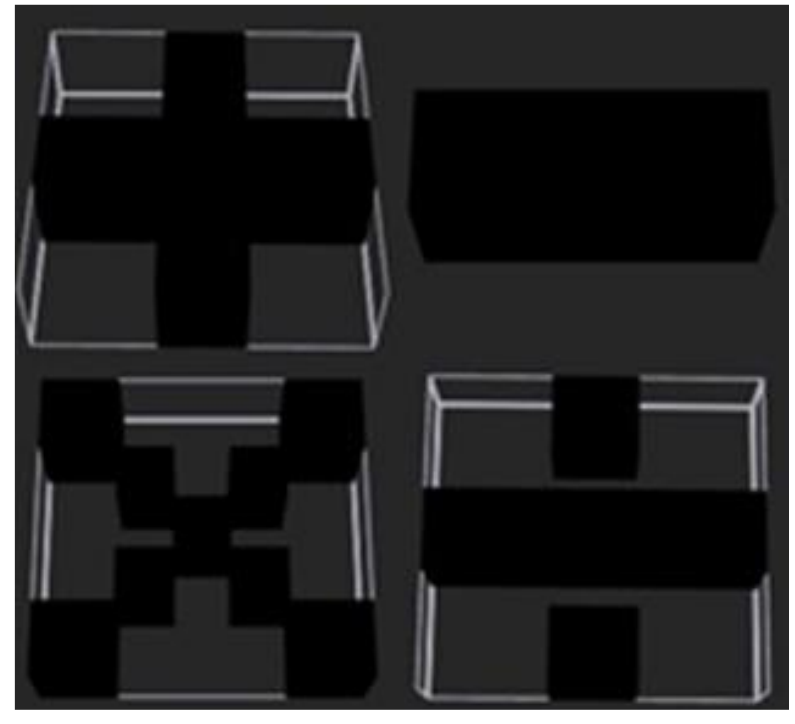

Fig. 12: Math symbols

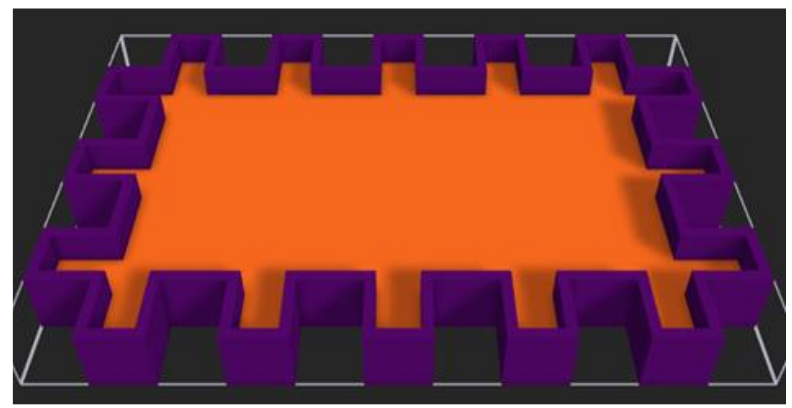

Fig. 13: Figure to mounting the logo and the name

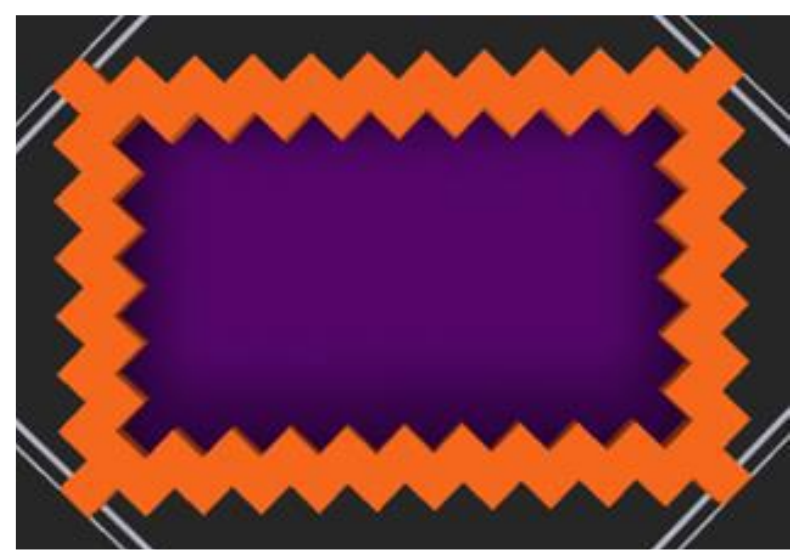

Fig. 14: Textbox

The name was used to be the marker, Fig. 9 shows it, so the rendering option was used, the name was put in the right position, the color was changed and the scene was exported in PNG. The marker is focused by the user to the camera of the electronic device (smartphone or tablet) and when is recognized the objects or figures made were showed in Augmented Reality.

After that, others 3D objects were done, those are mentioned below.

The numbers, Fig. 10 shows it.

Figures to represent fractions, Fig. 11 shows them, those were a pizza, a cake, a burger and a cookie.

Math symbols of addition, subtraction, multiplication and division, Fig. 12 shows them.

Figure to mounting the logo and the name, Fig. 13 shows it.

Textbox, Fig. 14 shows it.

Arrow, Fig. 15 shows it.

It is important to say that all the created objects were exported in the OBJ format to use them in the application develop.

\section{Construction Prototype}

The website Blippar was used for the construction of the Augmented Reality application, projects can be created in the environment in $3 \mathrm{D}$ or by scripts. All the projects are saved and are editable to any type of modification and they can be tested once by downloading the mobile application. An email account and a password are needed to enter to the website. In the website all the projects or Blipps created appear and also two options to start creating projects from the beginning as shown in Fig. 16.

To start creating a project, the option to select is create an AR project that works within a mobile app, the image that works as a marker is uploaded, the name is written and after a few seconds the development environment will be open to start to work with the project as shown in Fig. 17.

The development environment has a lot of tools, from default elements which can be used until a section to do short animations to the objects, also more scenes can be added to the project and in the right side there is a sidebar where object properties are showed.

Blippar has an original format, it is the M2D format to all the 3D models, so every time that a new model is upload it have to be convert in that format. This website has an own models converter, Fig. 18 shows it and to convert them, firstly they have to be in FBX format, once converted them at the ideal format the models are downloaded in a zip file. As it said in the Quick Design phase, all the models created were exported with the OBJ format because MagicaVoxel did not have the FBX format so Blender was use to convert OBJ to FBX.

Once all the models were converted to the M2D format, those were uploaded with their PNG file, this file was the texture. After that, the scenes were added to do every 
Hernández Pérez Andrea Ivonne et al. / Journal of Computer Science 2020, 16 (7): 1042.1062 DOI: $10.3844 /$ jessp.2020.1042.1062

interface of the application and also the models were added to the scenes; put them in the right position into the development environment. Every interface of the application created in Blippar is mentioned below.

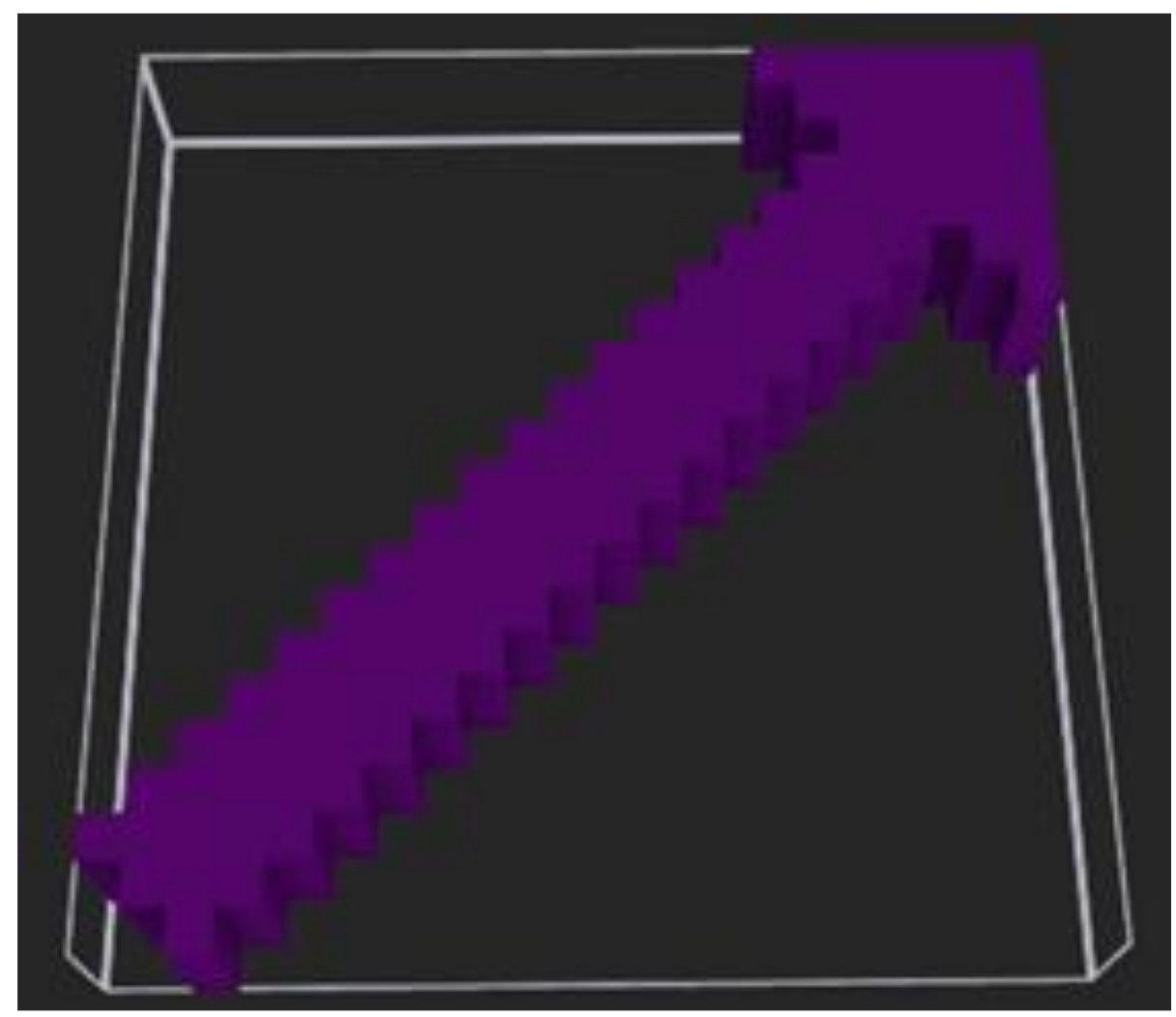

Fig. 15: Arrow

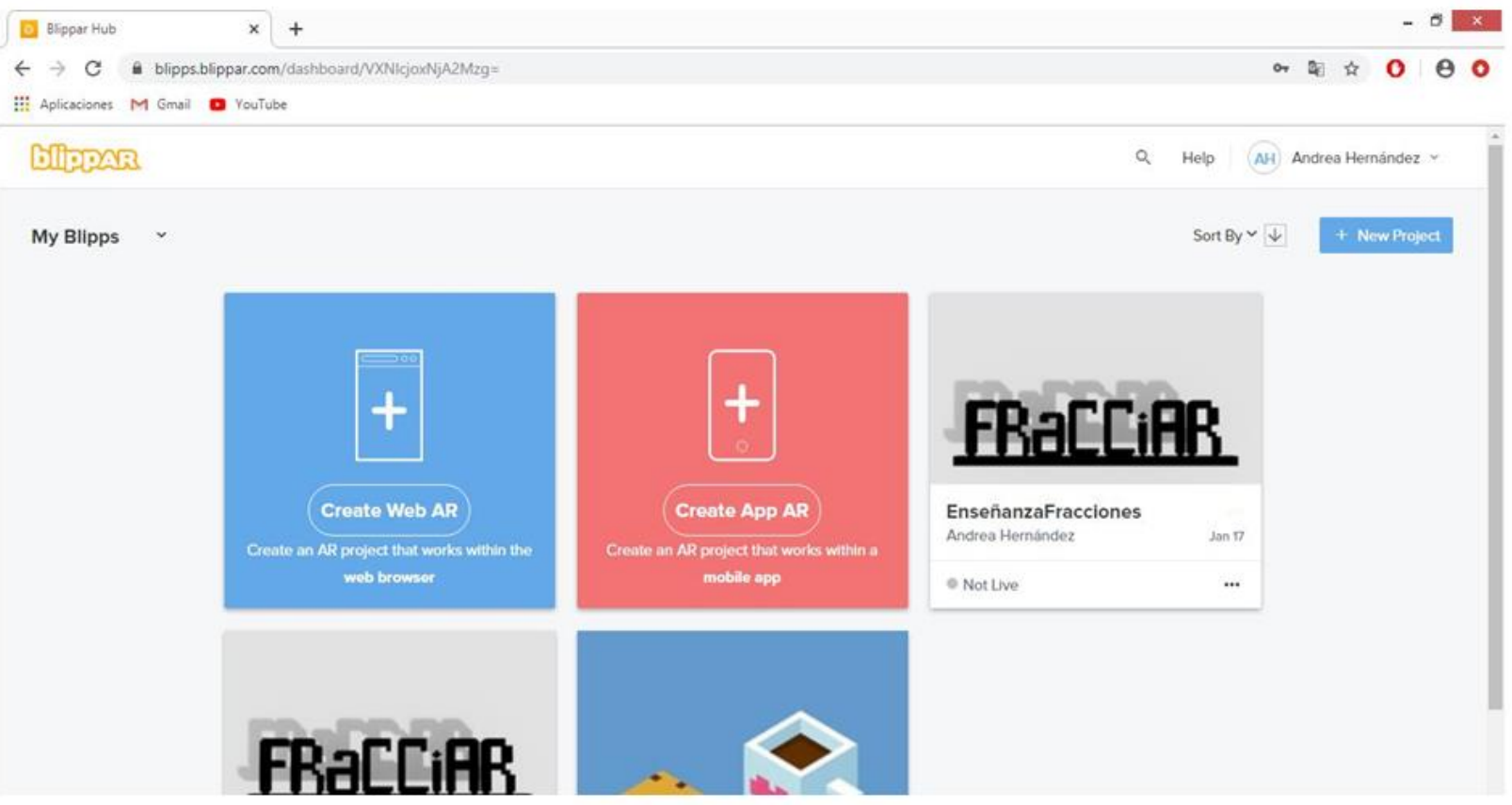

Fig. 16: Blippar website 
Hernández Pérez Andrea Ivonne et al. / Journal of Computer Science 2020, 16 (7): 1042.1062 DOI: $10.3844 /$ jessp.2020.1042.1062

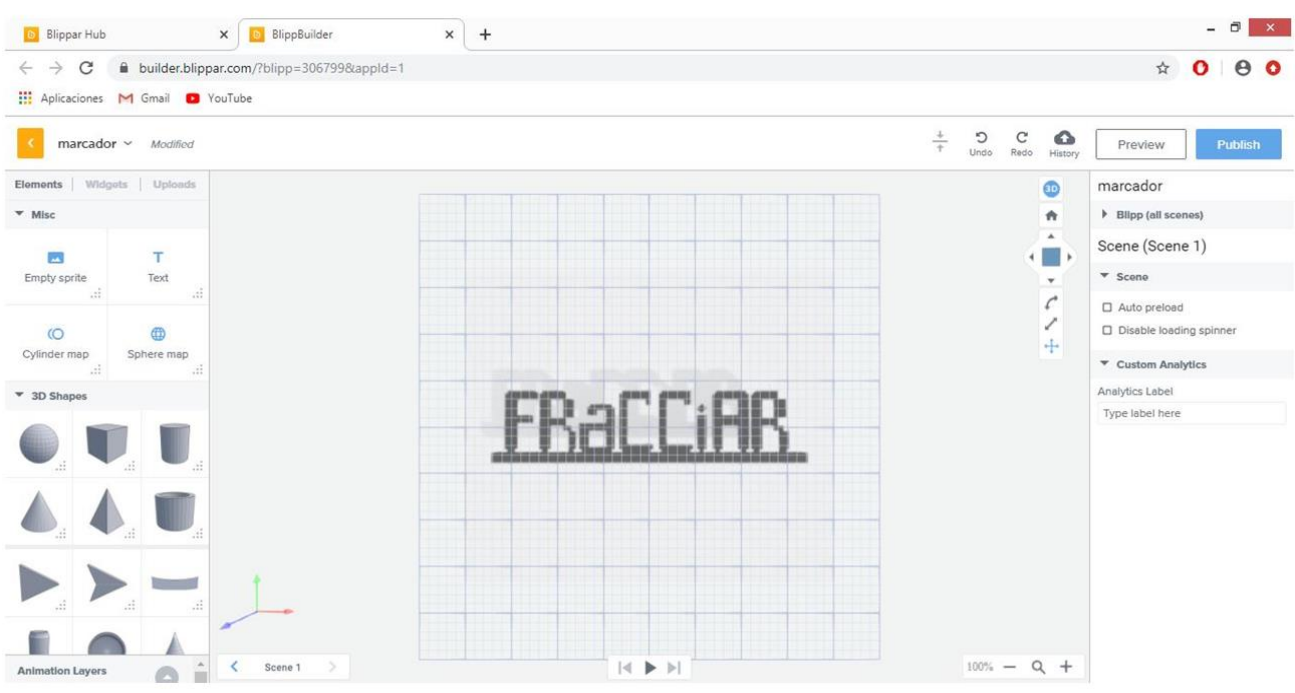

Fig. 17: Blippar development environment

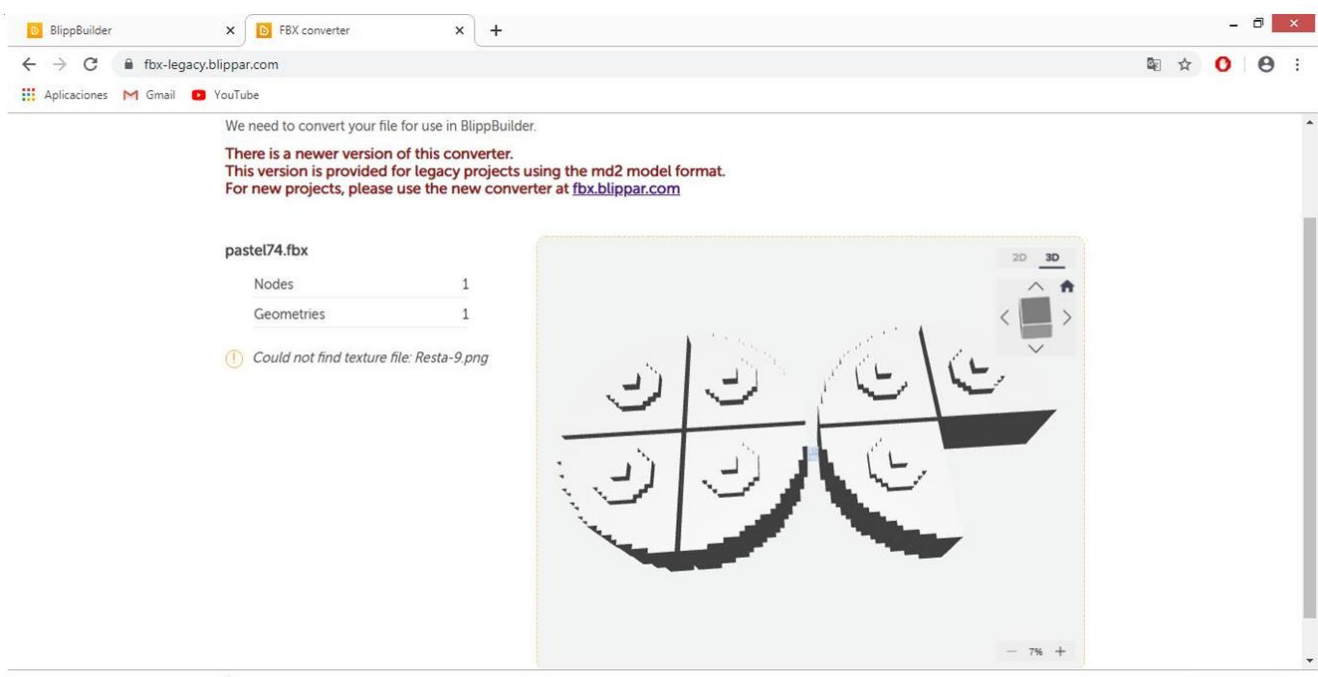

Fig. 18: Blippar models converter

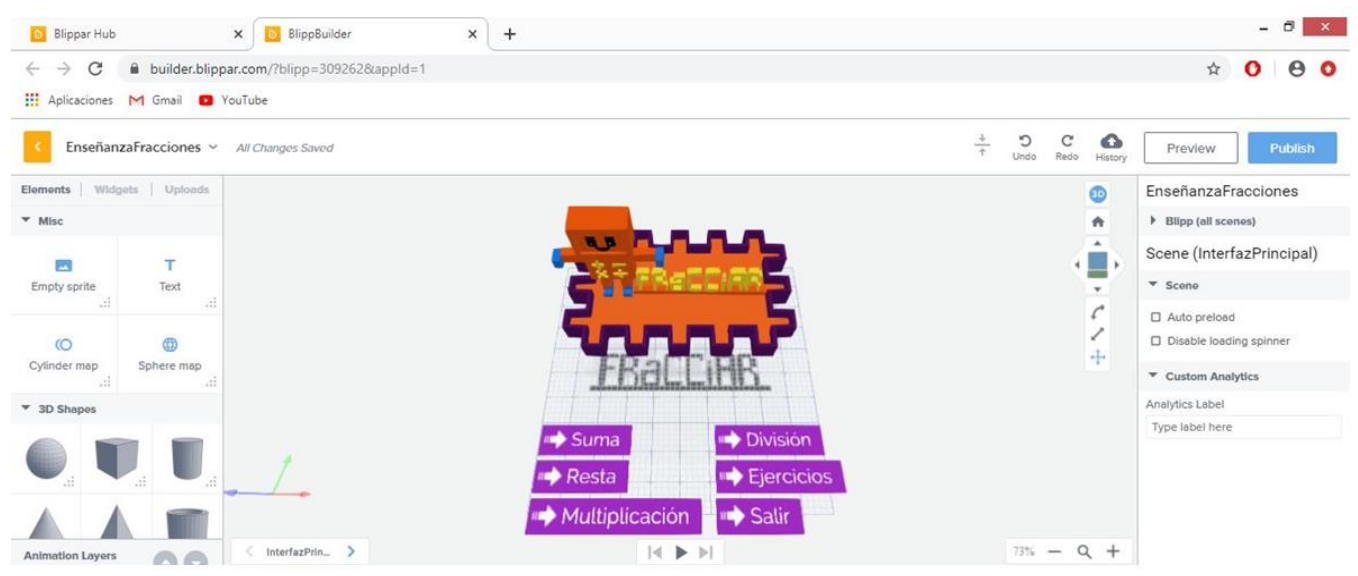

Fig. 19: Main menu interface 


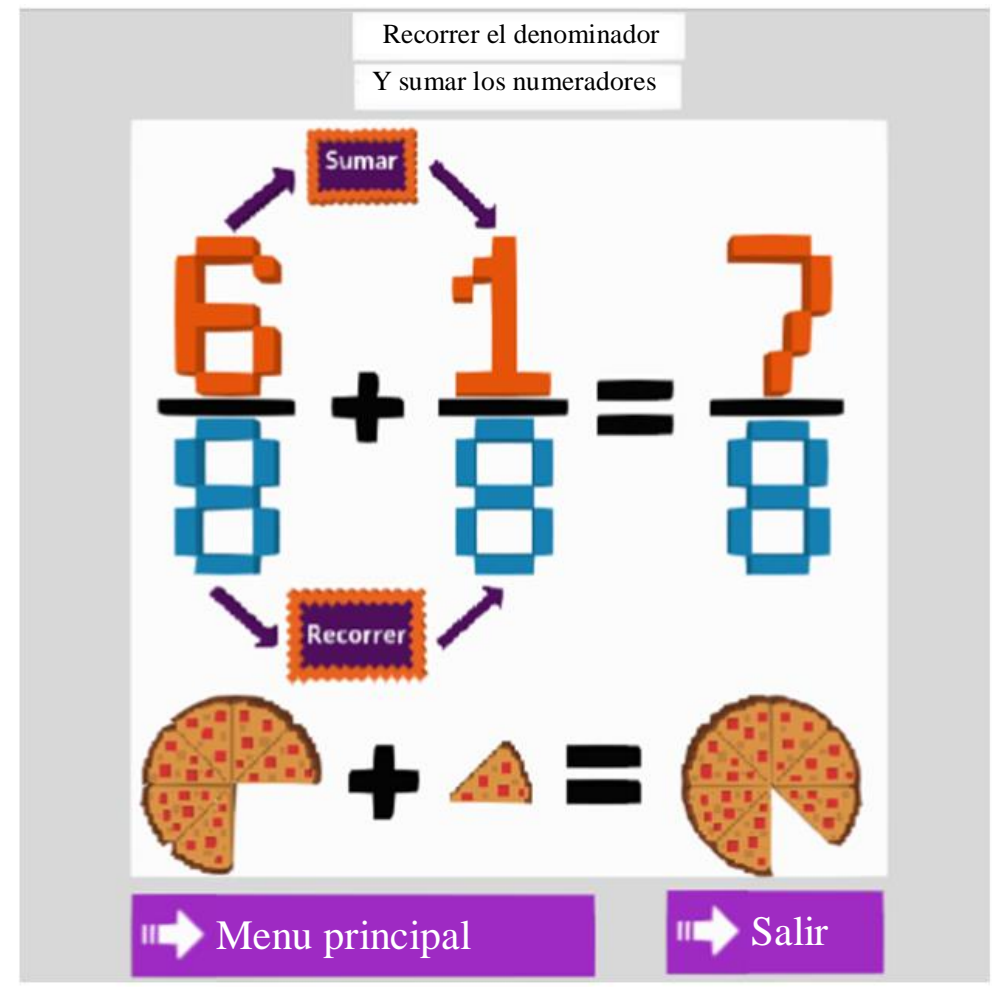

Fig. 20: Addition interface

\section{Main Menu Interface}

A short animation was used in this interface, this animation is in the figure where the logo and the name were mounting, is a movement from one position to another with a bounce-like motion. In the interface are the buttons of Suma, Resta, Multiplicación, División, Ejercicios y Salir (Addition, Subtraction, Multiplication, Division, Exercises and Exit) which ones the user can interact from the main menu to whatever interface as shown in Fig. 19:

- Addition Interface. Figure 20 shows all the process to do the addition operation, at the end appear the buttons of Menú Principal y Salir (Main Menu and Exit)

- Subtraction Interface. Figure 21 shows all the process to do the subtraction operation, at the end appear the buttons of Menú Principal y Salir (Main Menu and Exit)

- Multiplication Interface. Figure 22 shows all the process to do the multiplication operation, at the end appear the buttons of Menú Principal y Salir (Main Menu and Exit)

- Division Interface. Figure 23 shows all the process to do the division operation, at the end appear the buttons of Menú Principal y Salir (Main Menu and Exit)

- Exercises Interface. An exercise was done for each operation, this interface starts with the addition exercise and with the button of Siguiente Ejercicio (Next Exercise) all the other exercises pass one by one until the last one, so at the last exercise appear the buttons of Menú Principal $y$ Salir (Main Menu and Exit). In every exercise the operation to be solved is found and the answer options are the figures which represent the fractions, Fig. 24 shows it, to answer every exercise any figure have to be press, after that a sound will announce if the answer was correct or incorrect

\section{Exit Interface}

A short animation also was used in this interface, this animation is in the figure where the logo and the name were mounting, is a movement from one position to another with a bounce-like motion. The application ends with this interface as shown in Fig. 25.

It is important to say that at the beginning it was pretended to do a small manual with information about fractions and with the markers used but after, the application was done using an only marker and it was unnecessary to do the manual because it would have repetitive information and would generate a paper waste, for that reason, only the printed image with the marker is used to see the application in Augmented Reality. Figure 26 shows the application in Augmented Reality where the buttons of Suma, Resta, Multiplicación, División, Ejercicios y Salir (Addition, Subtraction, Multiplication, Division, Exercises and Exit) are showed. 
Figure 27 shows in Augmented Reality the Addition Interface with all the process to do the addition operation and at the end appear the buttons of Menú Principal y Salir (Main Menu and Exit).
Figure 28 shows in Augmented Reality an exercise to solve a multiplication and at the end appear the buttons of Menú Principal y Salir (Main Menu and Exit).

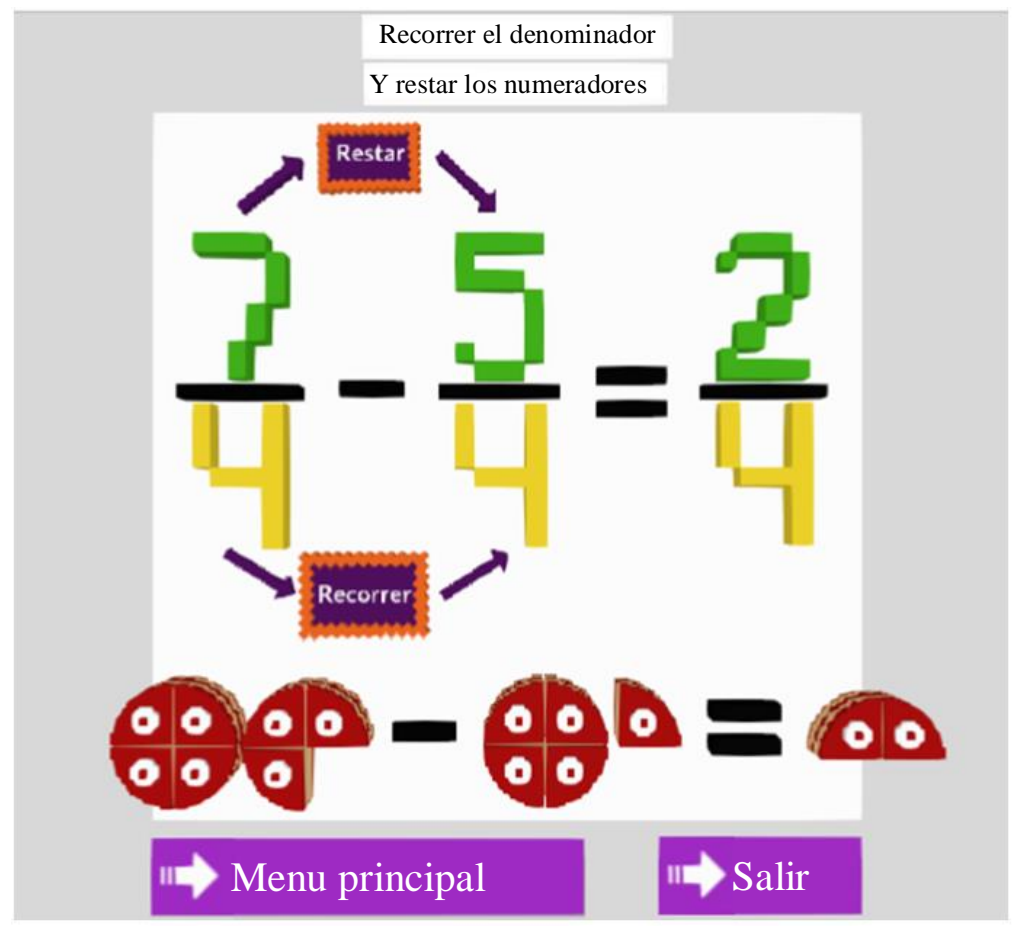

Fig. 21: Subtraction interface

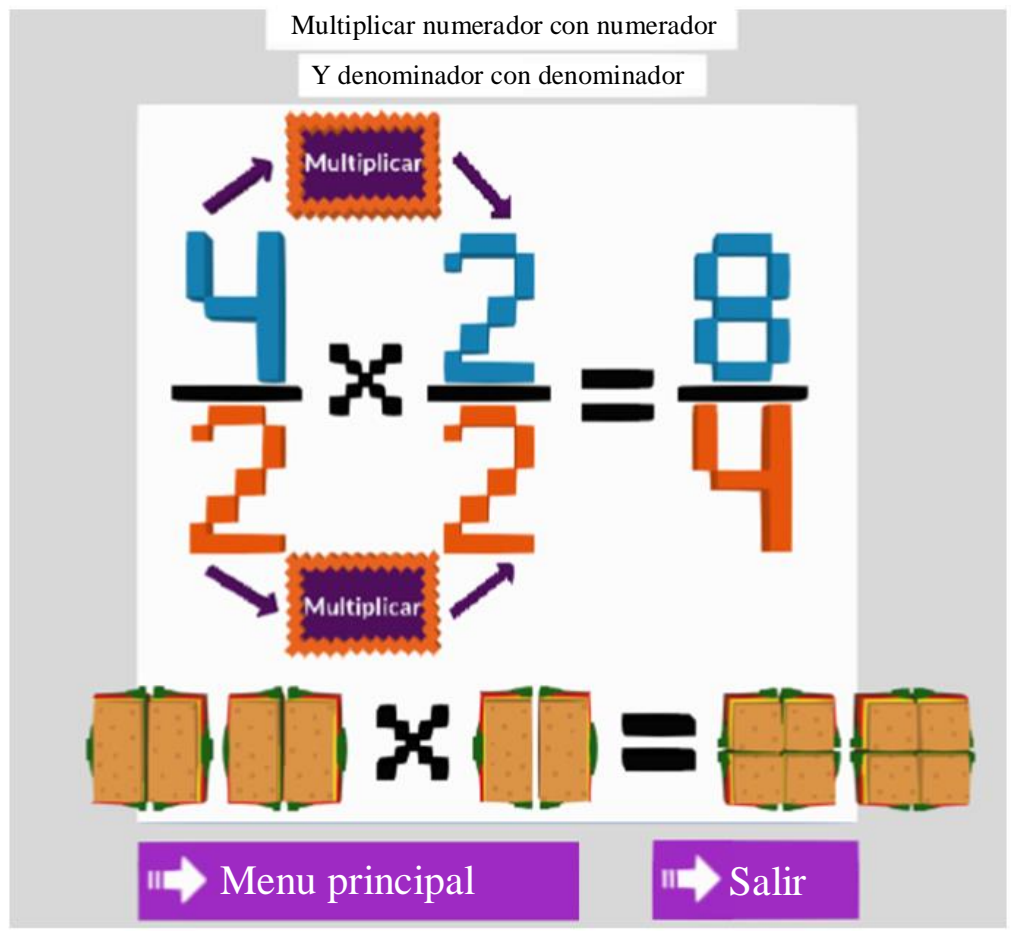

Fig. 22: Multiplication interface 


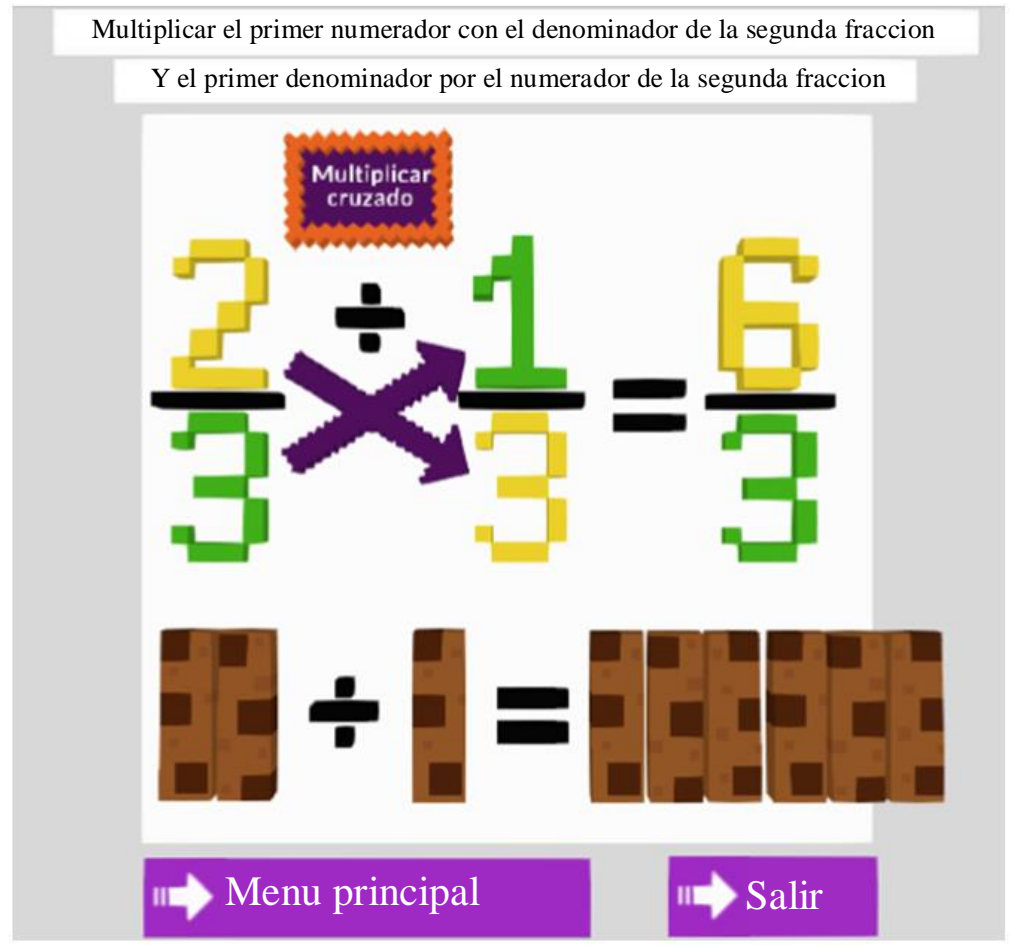

Fig. 23: Division interface

Presiona la fraccion de pizza correcta presiona la fraccion de pastel correcta
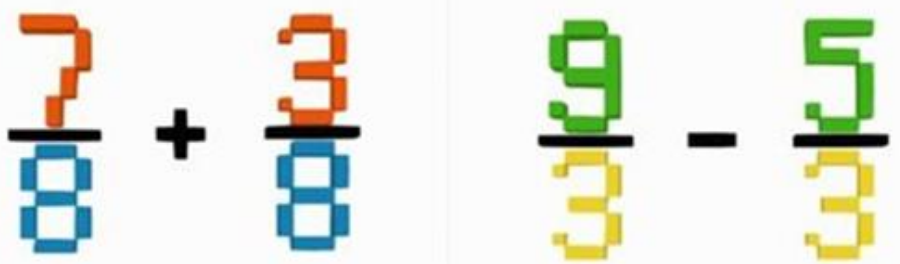

Siguiente ejercicio

Siguiente ejercicio
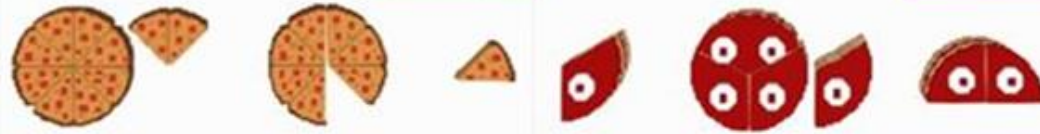

Presiona la fraccion de burger correcta presiona la fraccion de galleta correcta
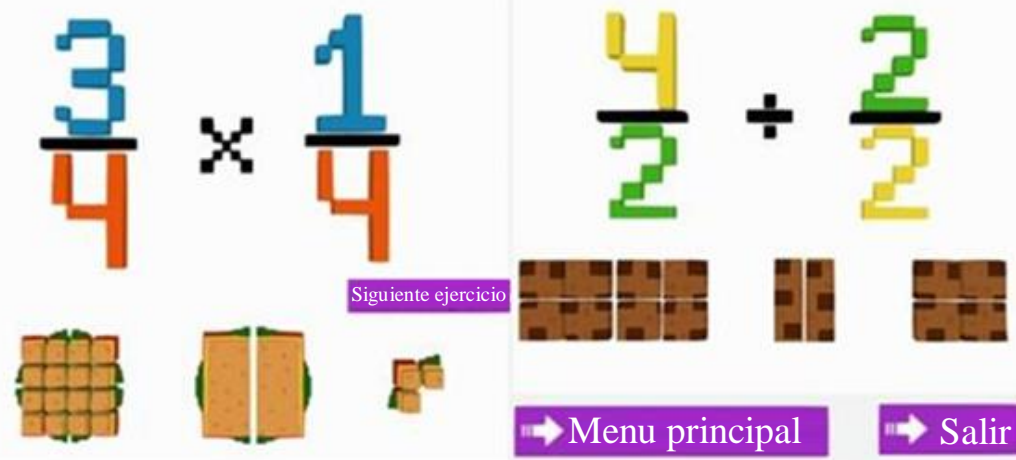

$\Rightarrow$ Menu principal

Salir

Fig. 24: Exercises interface 


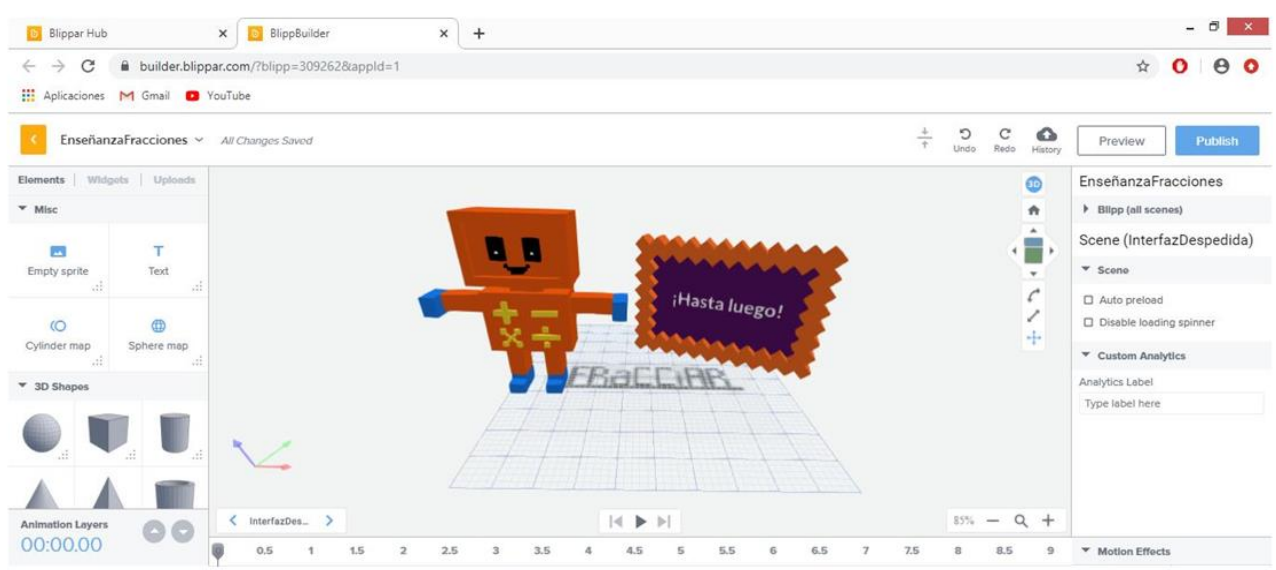

Fig. 25: Exit interface

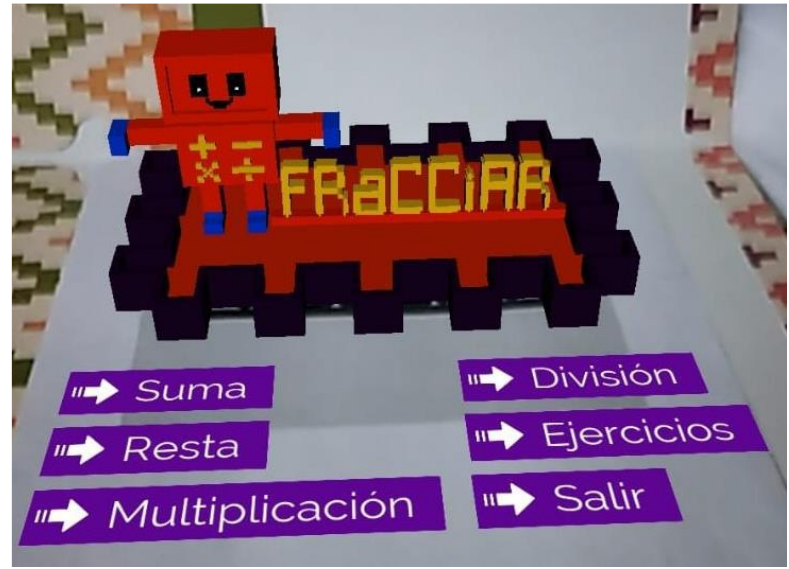

Fig. 26: Main menu interface in augmented reality

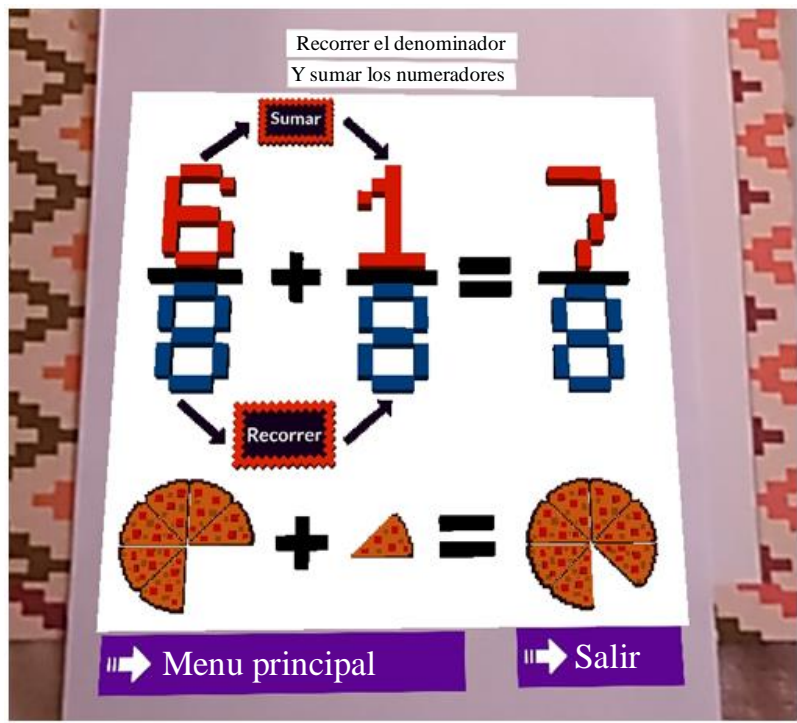

Fig. 27: Addition interface in augmented reality

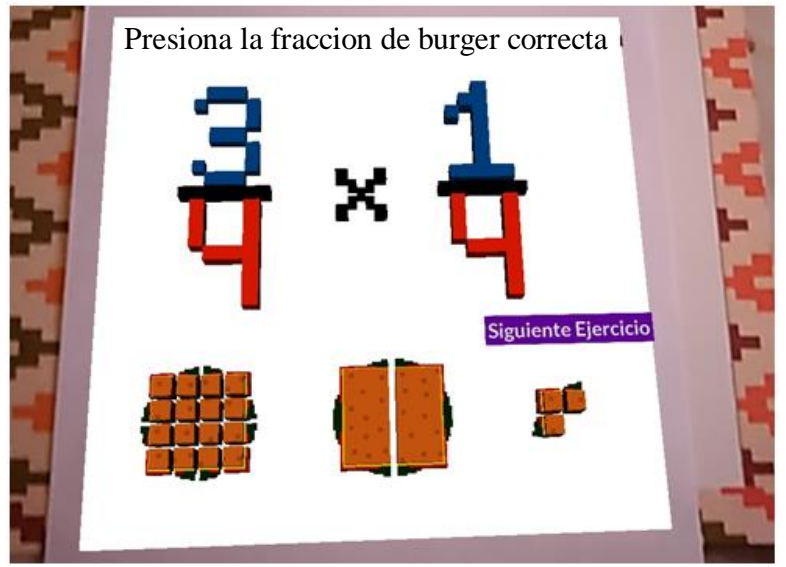

Fig. 28: Multiplication exercise in augmented reality

\section{Results}

\section{Deployment, Delivery and Feedback}

A demonstration of the application was done in a group of 14 fourth grade students of the Paulo Freire elementary school. First, an explanation about Augmented Reality was done, Fig. 29 shows it and the students participated giving their opinion about the topic.

After that, an explanation about the operation of the application was done, Fig. 30 shows it.

A smartphone and a tablet was given to each student to they would interact with the application, Fig. 31 shows it.

Once the students interacted with the application, a questionnaire was applied them, Fig. 32 shows it, this questionnaire had 6 Questions which helped to evaluate the application.

With the questionnaire answers, the following results were obtained. 
As shown in Fig. 33 to the $86 \%$ of the students the application was striking at first sight and only to the $14 \%$ of them the application was somewhat striking.

As shown in Fig. 34 to the $79 \%$ of the students comprehended totally the explained topic while the $21 \%$ of them did not comprehend totally.

As shown in Fig. 35 the $100 \%$ of the students considered that is more interesting to learn with the application.
As shown in Fig. 36 the $100 \%$ of the students liked the application.

As shown in Fig. 37 the $43 \%$ of the students considered that the application was easy to manipulate, the other $43 \%$ considered that was not too easy and for the $14 \%$ was not at all easy.

As shown in Fig. 38 the $93 \%$ of the students would like to learn more topics using an application like this and only to the $7 \%$ would not like at all.

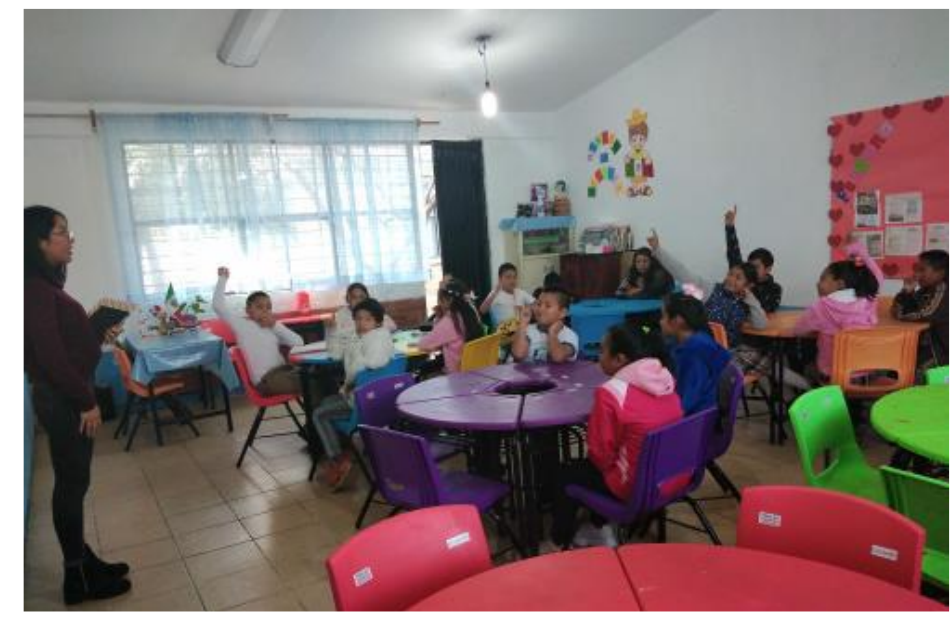

Fig. 29: Explanation about augmented reality

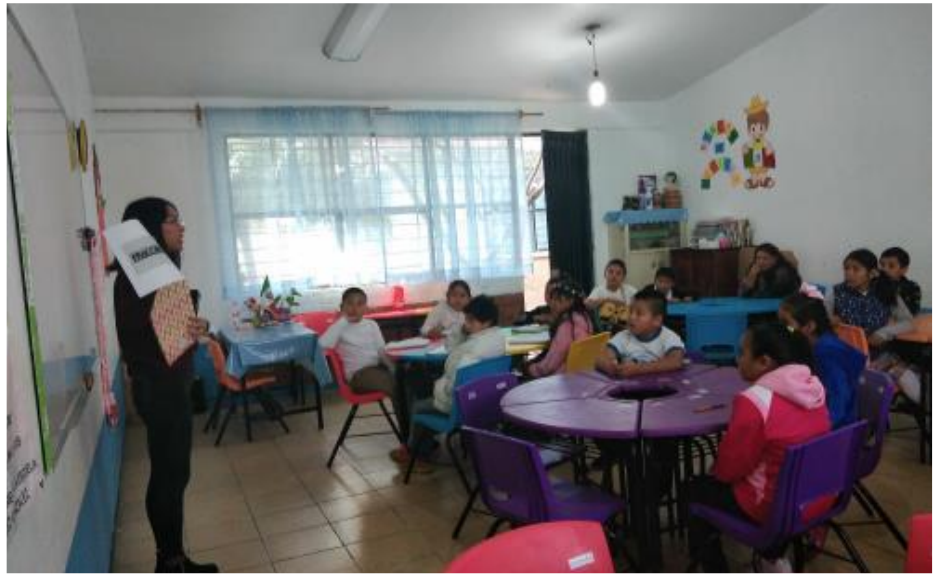

Fig. 30: Explanation about the operation of the application

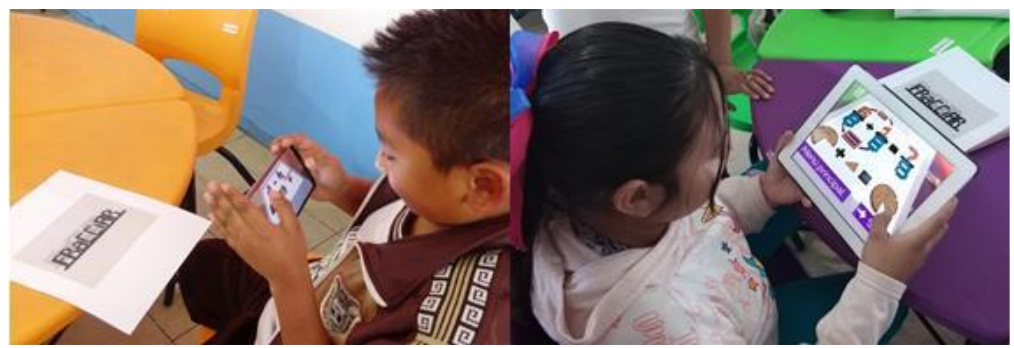

Fig. 31: Students interacting with the application 
Augmented reality application for teaching basic operations with fractions of the same denominator

Questionnaire to evaluate the application. Circle your answer. Thank you for the support.

1. Was the application striking at first sight?

$$
\text { Yes Somewhat No }
$$

2. Did you comprehend the topic explained in the application?
Yes
Somewhat
No

3. Was more interesting for you learn with this application?

$$
\text { Yes Somewhat No }
$$

4. Did you like the application?

Yes Somewhat No

5. Was the application easy to manipulate?
Yes
Somewhat
No

6. Would you like to learn more topics using an application like that?

Yes No

Fig. 32: Evaluation questionnaire to the application

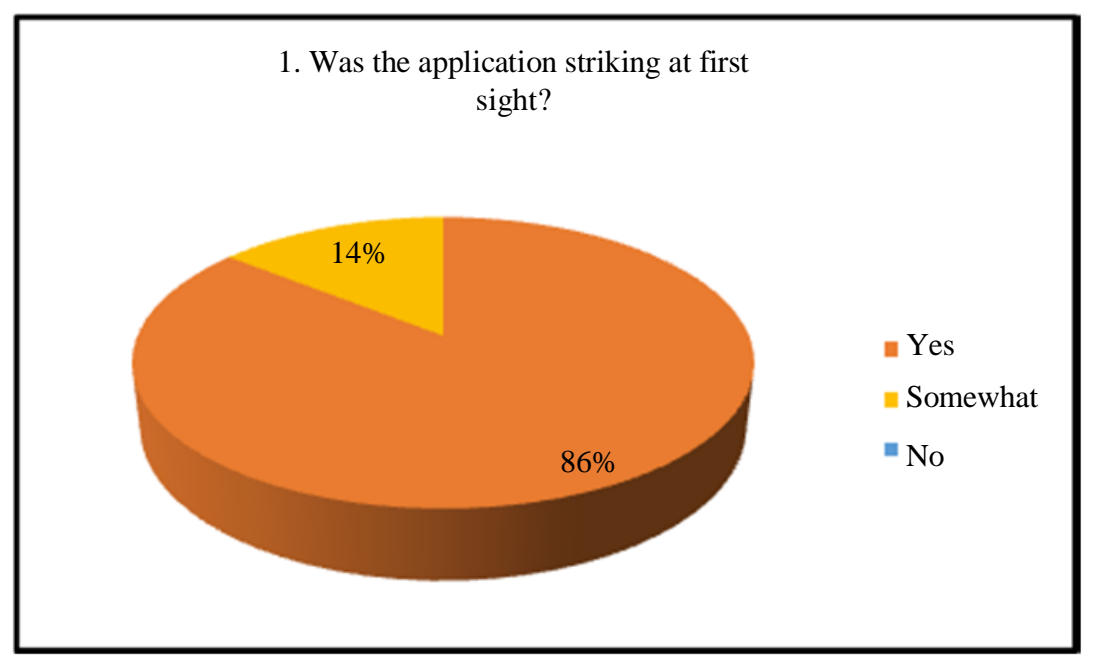

Fig. 33: Results of the question number 1 
2. Did you comprehend the topic explained in the application?

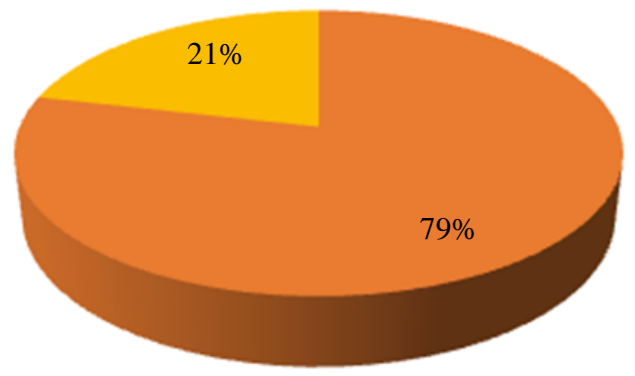

॥es

Somewhat

- No

Fig. 34: Results of the question number 2

3. Was more interesting for you learn with this application?

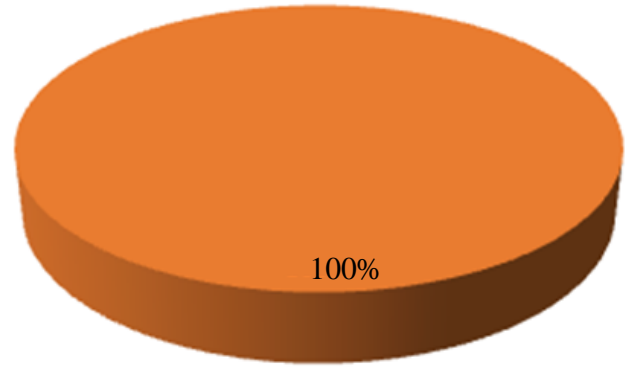

- Yes

Somewhat

믕

Fig. 35: Results of the question number 3

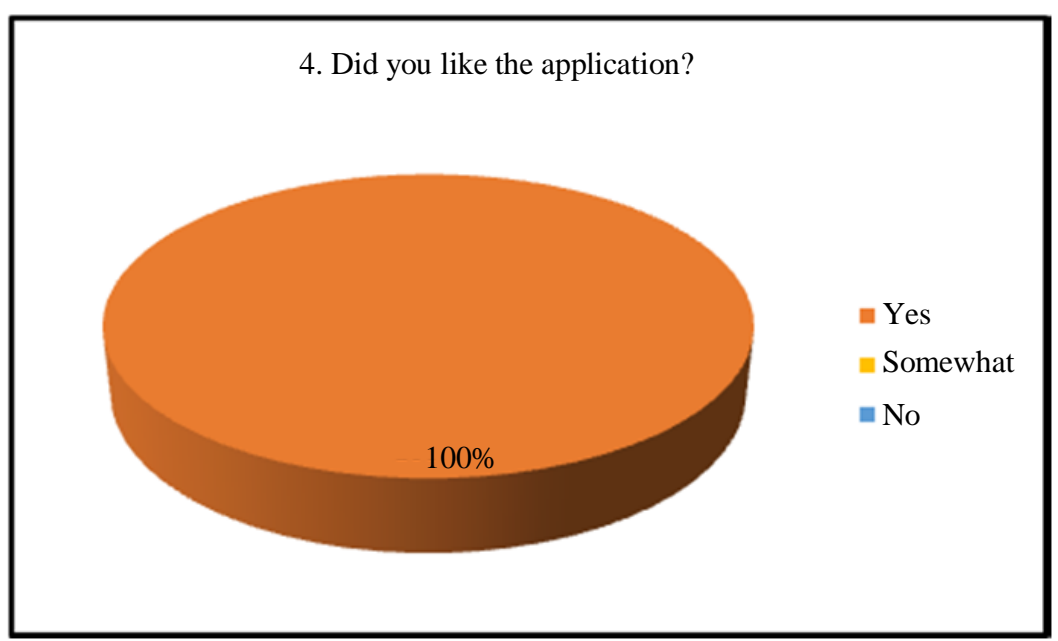

Fig. 36: Results of the question number 4 


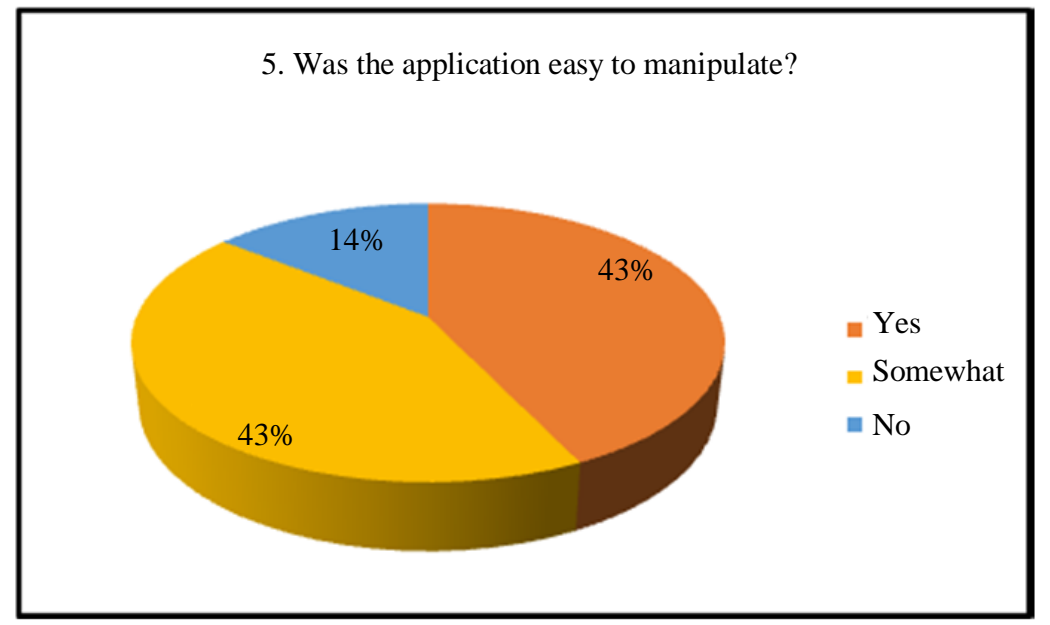

Fig. 37: Results of the question number 5

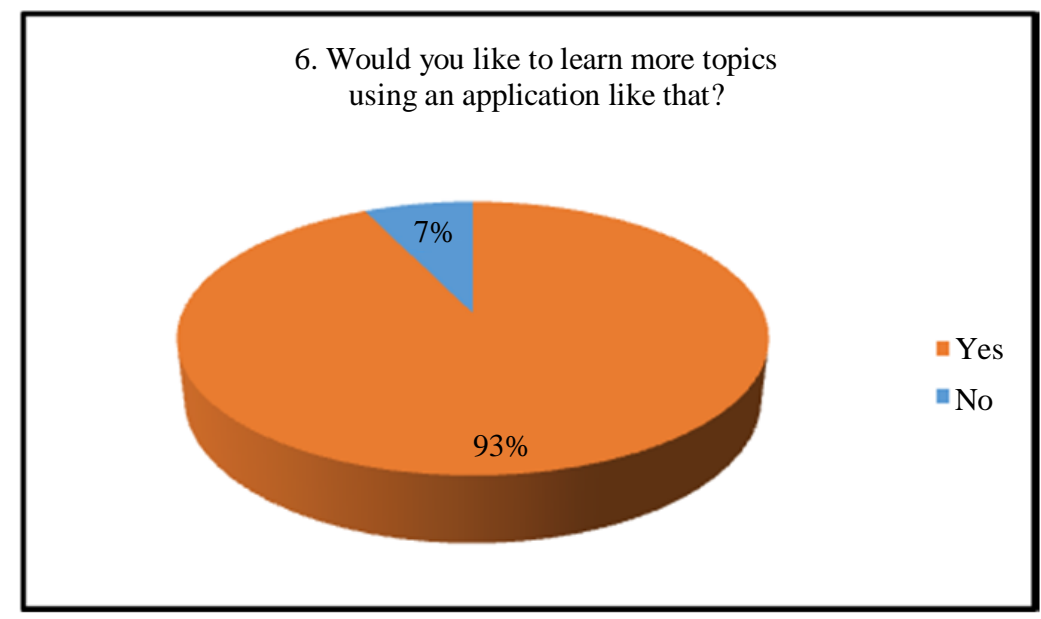

Fig. 38: Results of the question number 6

\section{Discussion}

This application can be implementing in different places, as for example, in government or private schools, also in home, in that way the students in a comfort place can continue learning and practicing the topic, only is necessary some electronic device (smartphone or tablet) to have this useful learning tool and nowadays a lot of people have those electronic devices or at least one of them, for that reason is better use those devices in the best way and take advantage of the technology in areas like the education, (Ramírez-Montoya and García-Peñalvo, 2017) in their work they focus in research about the integration, acceptance and the effective use of the mobile devices in the education and the learning.

More applications can be do focused to another topics, maybe in fractions topics but now in operations with different denominator or to another mathematic topic. Additionally, another scopes exist in where
Augmented Reality can be applied. In the work of (Muñoz and Montenegro, 2018) an Augmented Reality application which supports the teaching-learning process in the natural sciences scope was developed, specifically to the teaching and conservation of natural areas. The anatomy count with Augmented Reality applications too, as for example, the application of (Ramírez et al., 2018) which allows help to children in basic level learn human anatomy topics through the 3D models designed. An Augmented Reality application to the teaching of the robotic was designed and developed by (Mendoza et al., 2018) the application was considered as useful in the learning process, innovate and creative.

Also Augmented Reality books have been designed, as for example, in the work of (Abu-Arqoub et al., 2019) in where a learning system that is based on using Augmented Reality is described, in which a traditional textbook is converted to an interactive book using TAGs and multimedia to the comprehension of concepts in an 
interactive and funny way. Duarte (2018) developed an application and a book using Augmented Reality to improve and innovate the teaching process, achieving an impact in the improvement of the academic performance in elementary students.

Finally, in another research works, as for example, in the (Toledo and Sánchez, 2017) are focused in researching if the Augmented Reality as teaching tool favors the students learning. In the work of (Roig-Vila et al., 2019) examine the different perceptions about the use of Augmented Reality as didactic tool in the infant education. Both research works obtained positive, varying, interesting and promising results about the use of Augmented Reality in the education.

\section{Conclusion}

As a conclusion, based on the obtained results, the application was mostly well accepted; the students liked it a lot. The aim of comprehend totally the topic was met because the application helped them to comprehend it all the topic, the students considered to the application as very interesting, so that was another aim met, also they mentioned that with applications like that they learn better and in a more interesting, dynamic and funny way. While the students were interacted with the application, they were very interested and some of them said that they would like to learn more topics using Augmented Reality applications.

Using technologies like that to involve children in the new technologies, so they have a clue of what they could make with them is considered a good idea.

\section{Acknowledgement}

We are grateful to Centro Universitario UAEM Valle de Chalco, Paulo Freire Elementary School and with every student for participated in the demonstration of the application.

\section{Author's Contributions}

Hernández Pérez Andrea Ivonne: Designed and developed the application, writing and translating of the paper and researching all the information contained in the paper. Conducted experiments with fourth grade elementary students.

Mendoza Pérez Marco Alberto: Participated as adviser, collaborator in the application development and reviewer. Designed the research.

Cruz Flores René Guadalupe: Participated as adviser, collaborator in the application development and reviewer.

\section{Ethics}

This article is original and contains unpublished material. The corresponding author confirms that all of the other authors have read and approved the manuscript and no ethical issues involved.

\section{References}

Abu-Arqoub, M., Issa, G., Banna, A. E., \& Saadeh, H. (2019). Interactive Multimedia-Based Educational System for Children Using Interactive Book with Augmented Reality.

Azuma, R. T. (1997). A survey of augmented reality. Presence: Teleoperators \& Virtual Environments, 6(4), 355-385.

BBC, (2016). Qué es la realidad aumentada, cómo se diferencia de la virtual y por qué Apple apuesta fuertemente a ella. Recuperado de http://www.bbc.com/mundo/noticias-37678017

Blender, N. D. (2020). About. https://www.blender.org/about/

Blippar, N. D. (2020). blippAR. https://www.blippar.com/

Cárdenas, H. A, Mesa F. Y. and Suarez, M. J. (2018). Realidad Aumentada (RA): Aplicaciones y desafíos para su uso en el aula de clase. Revista Educación Y Ciudad, 35; (137-148).

Duarte, B. A, (2018). Impacto de la realidad aumentada y su aplicación para innovar el proceso de enseñanza primaria. J., Sci, Res, Revista Ciencia e Investigación, 3; (25-31).

EcuRed, N. D. (2019). Modelo de prototipos. https://www.ecured.cu/Modelo_de_prototipos

Educativo, P. (2011). Qué es una fracción? https://www.portaleducativo.net/quintobasico/531/Que-es-una-fraccion

Heras, L. and Villarreal, J. L. (2007). Realidad Aumentada: Una tecnología en espera de usuarios. Revista Digital.

López-García, J. D., \& Gutiérrez-Niño, D. (2018). Efecto del uso de la herramienta "realidad aumentada" en el rendimiento académico de estudiantes de Educación Básica. Revista Perspectivas, 3(1), 6-12.

Mendoza, M. A, Cruz, R. G. Villalba, A. A. and Arreola, E. (2018). Aplicación en Realidad Aumentada como recurso didáctico para la enseñanza de la robótica humanoide. Tecnologías y Aprendizaje: Investigación y Práctica.

Montecé-Mosquera, F., Verdesoto-Arguello, A., Montecé-Mosquera, C., \& Caicedo-Camposano, C. (2017). Impacto de la realidad aumentada en la educación del siglo XXI. European Scientific Journal, ESJ, 13(25), 129-137.

Muñoz, L. E. and Montenegro, R. (2018). Uso de la realidad aumentada en la enseñanza-aprendizaje de ciencias naturales. Revista Ingeniería Solidaria, 14; (9-9).

MVCW, (2020). MagicaVoxel. MagicaVoxel Community Wiki. 
Perán, L, (2014). VoxelArt. http://voxela rt.blogspot.com/2014/04/que-es-voxel-y-el-voxelart.html

Pérez, R, (2016). Realidad aumentada. Tecnología para la formación. EDUTEC, Revista Electrónica de Tecnología Educativa.

Prendes, C. (2015). Realidad aumentada y educación: análisis de experiencias prácticas. Píxel-Bit. Revista de Medios y Educación, 46, 187-203.

Pressman, R. S, (2010). Ingeniería Del Softwa Re. Un Enfoque Práctico. Mc Graw Hill, pp; (43).

Ramírez-Montoya, M. S., \& García-Peñalvo, F. J. (2017). La integración efectiva del dispositivo móvil en la educación y en el aprendizaje.

Ramírez, N. V, Laguna, M. Rubín, N. N. and Flores, A. (2018). Realidad aumentada: UNA aplicación móvil para educación básica. Pistas Educativas, 40; (1851-1861).

Reinoso, R, (2012). Posibilidades de la realidad aumentada en educación. Tendencias emergentes en educación con TIC.
Roig-Vila, R., Lorenzo-Lledó, A., \& Mengual-Andrés, S. (2019). Utilidad percibida de la realidad aumentada como recurso didáctico en Educación Infantil. Campus Virtuales, 8(1), 19-35.

Samihah, C, Kolivand, H. Ka Dhim, H. Shahrizal, M. and Billinghurst, M. (2017). Factors influencing the acceptance of augmented reality in education: A review of the literature. J, Comput, Sci, 13; (581-589).

Sanguino, R. (2019). Historia de las Fracciones. https://sites.google.com/site/cienciasnaturaleslbjb/ home

Telefónica, F. (2011). Realidad aumentada: Una nueva lente para ver el mundo, Fundación Telefónica, España.

Toledo, P. and Sánchez, J. M. (2017). Realidad aumentada en educación primaria: Efectos sobre el aprendizaje. Revista Latinoamericana de Tecnología Educativa, 16; (79-92). 